\title{
Hitoktatás a Csanádi Római Katolikus Egyházmegyében 1945 és 1956 között
}

1945-tól Magyarországon is megkezdódött a sztálini típusú totalitárius rendszer kiépitése. Ennek egyik következménye az lett,

hogy elkezdôdött a történelmi egyházak nyilt üldözése. A római katolikus egyház más, kelet-közép-európai országokhoz hasonlóan az intézményeinek fenntartását szolgáló földbirtokainak legnagyobb

részét már 1945-ben elveszitette. A diplomáciai kapcsolata a Vatikánnal megszünt. 1946-ban betiltották a hitbuzgalmi egyesületek müködését, az egyházi iskolákat és intézményeket 1948-ban államositották, 1949. szeptember 5-én fakultativvá tették a hitoktatást, majd 1950-ben erószakkal feloszlatták a szerzetesrendeket. Az egyházi javadalmakat elkobozták, az elvilágiasodás az állam minden részére kiterjedô propagandájának és a kiméletlen üldözéseknek köszönhetöen lassan kezdett elterjedni. Mindez nemcsak avégett történt, hogy a "Szentháromság-tant” letaszítva Sztálint és Rákosit ültessék a „trónra”. A dialektikus materializmus

szellemi áramlatát, a marxi és lenini elvek bevezetését tartották követendónek ahhoz, hogy a "népi demokrácia útján” egy másik, természettudományos alapú társadalmat neveljenek fel és hozzanak létre.

\section{Bevezető}

elen dolgozatunkban a szovjet mintájú hazai ateista nevelés politikai vonatkozásait vizsgáljuk a római katolikus Csanádi Egyházmegyében, a lekövethető történeti eseményeken keresztül 1945 és 1956 között. Erre kívánunk szorítkozni, neveléstörténeti és kateketikai-módszertani kérdésekkel nem foglalkozunk.

A tanulmány első részében a háború végétől történő vallás- és egyházellenes politikai történéseket tárgyaljuk. Szűk keresztmetszetében azon történeti eseményeket, amelyek a hazai katolikusság szempontjából relevanciával bírnak. Az egyházmegye hitéletét különös tekintettel az alapfokú hitoktatásra - a második részben tekintjük át, amelynek eredményeit a harmadik fejezetben foglaljuk össze.

Az időszak megismeréséhez fő forrásként a Szeged-Csanádi Egyházmegye Püspöki Levéltárában (SZCSPL.) fellelhető és még fel nem dolgozott, 1945 és 1956 közötti hitoktatói és lelkipásztori jelentések szolgáltak, valamint a Magyar Nemzeti Levéltár Csongrád Megyei Levéltárában (MNL-CSML.) archivált Csongrád Vármegye és Szeged Tan- 
felügyelőségének iratai, továbbá egyéb sajtóhírek adtak támpontokat. Az egyházmegyei papság munkájának letükröződéséről az 1946-1956 között kiadott püspöki körlevelekből is alkalmunk lesz olvasni, valamint lelkészi visszaemlékezések is adatokkal szolgáltak dolgozatunk elkészítéséhez. Bővebb ismeretet adtak még ehhez a témát részben feldolgozó publikációik, könyvek és folyóiratok.

Az elmondottakból következik, hogy csak a magyar római katolikus egyház hitoktatási ügyeit vizsgáljuk, a többi egyházét nem.

\section{A római katolikus egyház helyzete Magyarországon 1945 és 1956 között}

A második világégés előtt az állam és a római katolikus egyház kapcsolata más képet festett, mint a „felszabadulás” utáni Magyarországon. Az egyház a gyökerekig ható, a hitélet mellett a társadalmi, kulturális, oktatási, valamint a gazdasági életet is meghatározó erőként került ki a második világháborúból, amelyet nemcsak a Szentszék, hanem - „bevett” vallásfelekezetként - az állam is támogatott. Söt, beépült az ország mechanizmusába, és Trianonnak köszönhetően a többi felekezettel szemben a katolikusok száma volt a legmagasabb: 1910-ben a lakosság 49,3 százaléka, 1949-re 67,8 százaléka vallotta magát római katolikusnak. ${ }^{1}$

A katolikus egyház terjeszkedéséhez előzményként számba kell vennünk a következőket: A magyar katolicizmusra is hatottak azok az újkonzervativista szellemi áramlatok, amelyek az 1800-as évek végétől söpörtek végig Európa nagyobb országaiban. Ezt az időszakot a „Freiburgi Unió” létrejöttétől (1884), valamint XIII. Leó pápa Rerum novarum kezdetü szociális enciklikájának kiadásásától (1891) datálhatjuk, amelyben a klérus programot hirdetett Európa létproblémáinak megoldására a nagyhatalmak liberális szemléletü gazdaságpolitikáival szemben. A századelőre jellemzően a társadalmi fejlődés ideológiai és politikai válságának sürgetése azt a kérdést vetette fel, hogy a szekularizálódó polgári társadalom mellé az egyház miként tud felzárkózni. Fő probléma volt annak rendbe tétele, hogy a lelki vezetők élöszóban milyen lelki útravalót tudnak adni a nemesi birtokosoknak, továbbá a polgároknak és a paraszti, valamint kispolgári rétegeknek a kapitalista viszonyok között, amelyek végre nem a kényszerü asszimilálódás felé mutattak. Az eredmény egy reneszánszászát élő katolikus egyház képét mutatta országunkban, s egészen a szovjet típusú diktatúra bevezetéséig tartott.

Az önmagát megújítani akaró, 20. század eleji magyar katolikus hitélet történetében a „politizáló egyház” reformtörekvéseinek első artikulálója és a keresztény nemzeti ideológia megalapozója Prohászka Ottokár ${ }^{2}$ székesfehérvári püspök, hittanító, teológus volt. A szellemi forradalmat indító pap konzervatív iránymutatásaival szemben állt a szabadgondolkodással, a kényelmes polgári miliő adta jelenségekkel és a baloldali eszmékkel. Azokkal a francia forradalom után kialakult, a „modern kort” jellemző áramlatokkal, amelyek akkorra már az egyházban is kibontakozni látszottak. A változásokat elsőként a kléruson belül kívánta elindítani a megfelelő utánpótlás-neveléssel, a papképzés reformjával. A teológiailag felkészültebb lelkipásztorok képzése mellett fontosnak tartotta a katolikusság megjelenését a hazai politikában, aktívan részt vett a Katholikus Néppárt ${ }^{3}$ szervezésében, majd az Esztergom címü politikai hetilap kiadásánál is jelen volt (Gergely, 1977, 15-16. o.; Gergely, 1999). Munkásságára azon törekvés volt jellemző, hogy az avítt, feudális állam - feudális egyház színezetü múködés helyett a hívekkel szoros kapcsolatot ápoló, a kor kihívásaira állandóan és rugalmasan reagáló, élő egyház jöjjön létre.

Prohászka után a katolikus restauráció időszakának másik nagy alakja a jezsuita Bangha Béla ${ }^{4}$ Páter volt. A „sajtóapostol” virágoztatta fel a katolikus sajtóvállalatot, amely hatásos propaganda- és népszerüsítő eszköznek bizonyult. Irányításával a hazai 
sajtótermékek jelentős részét tették ki a katolicizmushoz kötődő folyóiratok és újságok. A keresztény középosztály öntudatra ébresztése, a keresztény nemzeti kultúra megjelentetése volt a cél, amelyben Bangha élen járt. Radikális, karakteres megnyilatkozásai által szélsőségesnek mondható hitvédő volt, ám elvitathatatlan érdemei voltak a keresztény-nemzeti gondolat megteremtésében.

Az első világháború előtti időkből induló megújhodási kísérletek katolikus politikai szerepvállalást, világnézeti alapon létrejövő érdekképviseleti és politikai szervezetek alapítását is eredményezték. A katolikus gondolkodás egyre jobban szerepet kapott a szociális jellegü társadalmi problémák megoldásaiban. Az első Giesswein Sándorhoz ${ }^{5}$, a keresztény munkásegylet megalapítójához füződő párt- és mozgalomszervezési kísérletek a Rerum novarum szellemében nyújtottak ezekhez alternatívákat. A katolikus gondolkodók és politikusok megkísérelték kidolgozni azt az akkor „reformkatolikusnak” nevezett politikai eszmerendszert, amely a korabeli társadalmi viszonyok reális elemzésén alapult, és amely a nyugat-európai kereszténydemokrata gondolkodás magyar megfelelöjeként dolgozott ki keresztény társadalmi és politikai alternatívát (Petrás, 2015, 83-85. о.).

A pozitív kibontakozásban még nagy szerepe volt az egyre jobban színre lépő nacionalizmusnak és revizionizmusnak is. Az egyház ugyanis tovább erősödött, a társadalom minden rétegébe beágyazódott a trianoni békediktátum aláírása után. A Bethlen-kormány konszolidációs politikájának egyik irányzéka a társadalom lelki kulturálódásának elösegítése volt, ellensúlyozva az ország gazdasági problémáit, amelyet az ország kétharmad részének elvesztése folytán volt kénytelen elszenvedni. A hazafias érzések, a nemzeti sérelmek ápolásában kivételes szerepet kapott, az oktatás és kultúra vezető szinten való kezelése jutott osztályrészül a katolikus vezetésnek. Példaként említve néhány szemléltető adatot: A háború idejére (1944-1945) 3846 aktív felszentelt pap müködött a határokon belül. A férfi szerzetesrendek összlétszáma 2429 fö, a női rendeké 10000 fő volt. 193 óvodában, 1216 népiskolában, 1669 általános iskolában, 86 polgári iskolában, 22 szakközépiskolában, 35 pedagógusképzőben és 1 jogakadémián láttak el oktatási, pedagógiai feladatokat (Mészáros, 1989, 51. o.). De tartottak még fenn tudományos társaságokat, szociális és egészségügyi intézményeket is. A közjogi és politikai életben ugyanúgy erős befolyással bírtak a Horthy-vezetés alatt: 1926-tól az egyházmegyei elöljárók helyet foglalhattak az Országgyűlés felsőházában, majd az 1937. évi XIX. törvény alapján lehetőség nyílt, hogy a kormányzói tiszt megüresedése esetén egy olyan „országtanács” álljon fel, amelyben a miniszterelnök és a két házelnök mellett a negyedik tag a mindenkori hercegprímás (Orbán, 1962, 27. o.).

Ezreket vontak köreikbe a katolikus vallási mozgalmak és hitbuzgalmi egyesületek.

Az egyház felfokozott korszakának megkoronázása volt a XXXIV. Nemzetközi Eucharisztikus Világkongresszus, amelyet Budapesten, a Hősök terén rendeztek meg 1938-ban, Szent István király halálának 900. évfordulójának tiszteletére.

Az alábbiakban tekintsük át azon politikai történéseket, amelyek által a kitüntetett „államegyház” pozícióból néhány éven belül a kommunista diktatúra térdre kényszerített rabszolgájává változott az egyház.

Az 1945 utáni kálvária szomorú és vészt jósló eseményekkel kezdődött. Elsőként három olyan súlyos történés is végbement mindössze néhány hét leforgása alatt, amelyek megingatták a klérus müködését. 1945. március 15-én az Ideiglenes Nemzeti Kormány Debrecenben elrendelte a 100 holdon felüli birtokok, köztük az egyházi földek kisajátítását és kiosztását, kártalanítást ígérve. Március 29-én életének 61. évében elhunyt Serédi Jusztinián bíboros hercegprímás, esztergomi érsek. Április 2-án báró Apor Vilmos győri püspök a kórházban belehalt egy szovjet katona puskalövéseitől elszenvedett sérüléseibe, amelyeket akkor szerzett, amikor védtelen nőket védelmezett a szovjet katonák megbecstelenítése elől. Majd április 4-én a Szövetséges Ellenőrző Bizottság (SZEB) - azaz 
gyakorlatilag a Szovjetunió - követelésére megszakadtak a diplomáciai kapcsolatok Magyarország és az Apostoli Szentszék között. Angelo Rotta pápai nunciust kiutasították Magyarországról. Az indoklás: az Apostoli Nunciatúra a nyilas hatalomátvétel után is Budapesten maradt, s a hatalommal érintkezve de facto elismerte azt (Balogh és Gergely, 1993, 249-316. o.).

A továbbiakban állami reformok gondoskodtak az ideológiai átnevelésről, valamint az egyház további gyengítéséről. Igaz, ekkor még csak „,belső” eszközökkel, nélkülözve a nyilvánosságot. Az Ideiglenes Nemzeti Kormány programja leszögezte, hogy „biztosítani kell a teljes vallásszabadságot”. A vallásszabadság biztosítása azt jelentette, hogy valamennyi egyház és hívő akadálytalanul, szabadon végezhette vallásos tevékenységét. A kormány (akkor) nem lépett fel azzal az igénnyel, hogy az egyházakat az államtól leválasszák. Így lehetett például Sík Sándor ${ }^{6}$ piarista egyetemi tanár, katolikus költő 1945-től az Országos Köznevelési Tanács ügyvezető elnöke. A vallásszabadság biztosítása azonban közelről sem jelentette a katolikus egyház korábbi közéleti, gazdasági privilégiumainak csorbíthatatlanságát. A kormány már ekkor akadályokat gördített a nagyszámú katolikus pedagógiai és sajtókiadvány kiadása elé (Gergely, 1985, 11-14. o.). Teleki Géza ${ }^{7}$ kultuszminisztersége alatt rendelet intézkedett a tankönyvek felülvizsgálatáról és az iskolai könyvtárak revíziójáról. Nem véletlen, hiszen az oktatási intézmények legnagyobb részben egyházi kézben voltak. 1945. június 28-án a tanügyigazgatás állami kézbe került, s ekkorra lett országos lefedettségü a Magyar Demokratikus Ifjúsági Szövetség (MADISZ) szervezete a Magyar Kommunista Párt rejtett irányítása alatt. Augusztusban pedig bevezették a nyolcosztályos alapfokú oktatást (amelyet már a háború előtt kidolgoztak, de az új tanügyi helyzet további revansokat adott ezzel a diktatúra kezébe), és a korábbi nyolcosztályos gimnáziumi tanítást négyévesre változtatták, a tankötelezettség pedig a 6-tól a 14. életévig tartó mindennapos iskolába járásra vonatkozott onnantól (Mészáros, 1996, 100-101. o.). A „finom eszközök” igénybevétele annak okán éleződött a koalíciós időszakban a kommunisták részéröl, hogy Rákosiék tisztában voltak a katolikus egyház társadalmi beágyazottságával. Tudták, hogy a „függöny elé lépni” lehetetlenség lett volna egyházellenességükkel. Három év „szalámi-politika” és küzdelem kellett még ahhoz, hogy céljukat elérjék. A sikerességüket azonban nem bízták a véletlenre: Rákosi Mátyás ${ }^{8}$ utasítására már 1946 tavaszán létrehozták az Államvédelmi Osztály III. alosztályaként az egyházpolitikai csoportot. Ez kétféle munkát jelentett: egyrészt gyüjtötte a nyilvánosan megszerezhető dokumentumokat, beszédeket és cikkeket, másrészt operatív úton titkos adatgyüjtést végzett. Különösen Mindszenty József ${ }^{9}$ levelezését és látogatóit, látogatásait kísérték figyelemmel. Ismerték a legbizalmasabb püspökkari ülések jegyzőkönyveit, sőt az ott elhangzott, jegyzőkönyvekbe nem került gondolatokat is (Lénárd, Tímár és Soós, 2008, 9. o.).

1945 októberében XII. Pius pápa Mindszenty József veszprémi püspököt nevezte ki esztergomi érsekké, akinek további nehézségekkel kellett szembesülnie. A kormány földreformjának következtében az egyház birtokainak nagyobb részét elveszítette. Kártalanítás nélkül az állam elvette a több mint 860000 katasztrális holdnyi földterületét, ami onnantól megnehezítette intézményeinek fenntarthatóságát. Az államosított birtokok nagy része ugyanis az oktatást, az egyházi intézményrendszer fenntartását szolgálta. Rákosiék pontosan tudták, ha az egyházi (legyen az katolikus vagy protestáns) intézményeket fenntartó anyagi alapokat felszámolják, az egyházkormányzat könnyebben „,rávehetö", hogy lemondjon az iskoláiról.

Az 1945. november 4-i parlamenti választásokon a Magyar Kommunista Párt kevesebb, mint húsz százalékos támogatást kapott a választóktól, mégis a megyék vezetése, a rendőrség és a politikai karhatalom irányítása Rákosiék kezébe került. A kommunista garnitúra a lakosságot szovjet mintára kívánta meggyőzni az új állami berendezkedés pozitív jelentőségéről. Az 1946 márciusában elfogadott, „hóhértörvénynek”10 titulált 
parlamenti jogszabály lehetőséget adott arra, hogy a fizikai kényszertől, internálásoktól se riadjanak vissza annak érdekében, hogy a népi demokratizálódás útjára „tereljék” a társadalmat. Legtöbb problémájuk a magyar katolikus egyház nyilatkozatainak politikai térben való megjelentetésével, illetve Mindszenty bíboros legitimista törekvéseivel, és a hercegprímás hívőkre nagymértékben ható karizmatikus erejével volt.

Az 1946 nyarán a budapesti Teréz körúton történt gyilkosságot is az egyházzal való leszámolásra használta fel a politikai rendőrség. Az ittas állapotban lévő orosz katonák egymás közötti véres konfliktusa jó ürügy volt ahhoz, hogy Rajk László belügyminiszter rendeleti úton feloszlathassa a Magyar Cserkészszövetséget és összesen több mint 1000 civil és egyházi jellegü egyesületet. Megkezdődött a civil társadalom intézményeinek szétverése is, a következő egy év során az egyházi szervezetek mellett vallási, kulturális, társadalmi és ifjúsági szervezeteket, valamint egyesületeket oszlattak fel (Gyarmati, Botos, Zinner és Korom, 1988, 157-159. o.). Államosították a katolikus nyomdákat, a lapokat és a könyvkiadókat. A hitbuzgalmi egyesületek társadalmi szerepét az „új világ” ideológiáját hirdetô, újonnan alakult ifjúsági szervezetek váltották fel. Ekkor létesült a Magyar Ifjúság Országos Tanácsa (MIOT), az egyes ifjúsági szervezeteket, főként az egyes pártok ifjúsági szervezeteit tömöríteni és irányítani kívánó csúcsszerv, továbbá a magyar úttörőmozgalom és a Népi Kollégiumok Országos Szövetsége (NEKOSZ), amely a népi kollégiumokat tömörítette egységes szervezetbe, egységes nevelési elveket kívánva érvényesíteni bennük, föleg a Magyar Kommunista Párt és a Nemzeti Parasztpárt iránymutatása nyomán. Megalakult még 1946 nyarán a Központi Iskolai Sport Egyesület, amelyet később Iskolai Sportközpontnak, majd még később Diákszövetségnek neveztek (Mészáros, 1996, 102-103. o.).

Az egyre nagyobb méreteket öltő egyházellenes propaganda tökéletes példája Páter Kiss Szaléz ferences szerzetes vértanúhalála 1946-ban. A háború után Kiss megalapította a Keresztény Demokratikus Ifjúsági Munkaközösséget (KEDIM), amely szervezet nagy sikerrel vonzotta magába a fiatalságot. Vasárnaponként 500-600 lelkes középiskolás fiú és lány vett részt az összejöveteleken. A közösség 1946-ra már veszélyt jelentett a kommunistáknak, Kiss Szalézt és társait a politikai rendőrség letartóztatta. Gyöngyösön vallatták társaival együtt, ennek módszeréről egy visszaemlékező vádlott-társ ad hiteles képet:

„Este 10 órakor kezdődött a kihallgatásom. Leültettek egy szoba közepére állított hokedlire. Bejött vagy tíz legény, körbefogtak, elkezdtek ütni kézzel, bottal, ahol értek. Kirúgták alólam a hokedlit, letepertek és rugdostak. Az első ütésekkel kificamították az állkapcsomat. Ez az ütés egyik verőlegény speciális ütése volt, több bajtársamnak kitörte az állkapcsát. Verés közben kérdezték: hol a fegyverraktáram, hány embert öltem meg. Ez így ment félórás szünetekkel reggelig. Reggel aláírattak velem egy köteg jegyzőkönyvet, de nem tudtam, hogy mit tartalmaztak. Ezeket egy külön szerkesztőcsoport készítette."

Kiss Szalézt és társait a magyar hatóságok átadták a szovjet katonai ügyészségnek, s a mindenfajta törvényességet nélkülöző perben a ferences szerzetest golyó általi halálra ítélték. Elítéléséhez jó ürügyet jelentett, hogy több középiskolás fiú orosz katonák ellen fegyveres merényletet követett el Gyöngyösön. A koncepció szerint Kiss Szaléz biztatta fel a hozzá rendszeresen járó és a KEDIM-hez valamilyen módon kötődő fiúkat. Valószínüsíthető, hogy kivégzésére Sopronkőhidán került sor. Jellemző módon a szerzetes sírja máig ismeretlen (Máthé, 2011, 77-88. o.).

A kommunisták a fakultatív hitoktatás kérdését először a Független Kisgazdapárttal tárgyaltatták és hozták rajtuk keresztül nyilvánosságra, mentve magukat mindenféle politikai felelősségtől. Az 1947. február 28-i kisgazdapárti bizottsági ülés után a koa- 
líciós felek egyetértettek a fakultatív hitoktatás bevezetésének szükségében. Az ügy nem maradt titokban, az Új Ember katolikus hetilap már március 2-án tiltakozott. Mindszenty április 12-én táviratban ugyancsak tiltakozott Ortutay Gyula ${ }^{11}$ kultuszminiszternél annak bevezetése ellen (Gergely, 1985, 53-54. o.). A Szülők Szövetsége és az egyháziak tiltakozása mellett országos demonstrációk sorozata kezdődött, amelynek következtében a választható vallásoktatás lekerült a napirendröl.

1947 nyarán már az MKP az augusztus 31-re kiírt országgyűlési megmérettetésre készülve, a választási siker érdekében az újra összeállított névjegyzékből közel egymillió embert hagyott ki (Mindszenty, 1989, 179. o.). Pontosan azokat, akikről tudni vélték, hogy nem szimpatizálnak a rendszerrel. A választáson csak 22 százalékos eredményt értek el, mégis a baloldali blokk létrehozásával fondorlatos módon többségbe kerültek. Az MKP vezetése egy ernyőszervezetbe tömörítette magukkal a szociáldemokratákat, a Nemzeti Parasztpártot és a Szakszervezeti Tanácsot, amely utóbbi a Parlamenten kívülről segítette őket. Fő cél a kisgazdák kiszorítása volt a hatalomból. Azzal illették öket, hogy pártjuk jobboldali szellemiségü tagjai a földreform ellen, valamint más, demokrácia elleni cseleken dolgoznak.

Eközben az egyház társadalmi elfogadottsága, kedveltsége egyre jobban növekedett. Tömegek látogatták a meghirdetett Mária-év rendezvényeit (hivatalosan meghirdetve: 1947. augusztus 15. - 1948. augusztus 15.), amely országos programsorozat ténylegesen 1947 nyarától egészen 1948 decemberéig tartott.

Az ünnepi rendezvénysorozat folyamán Mindszenty mintegy 60000 zarándok előtt tartott szentmisét 1947. augusztus 15-én Esztergomban. Az egyházvezető világos evangelizációs programot állított a magyar katolikus közösség elé. Jól tudta ugyanis, hogy a támadások ellen a magyar egyház legnagyobb védelme az, ha belsőleg minél erősebb. Nem anyagiakban, nem birtokkal, nem gazdasági-pénzügyi téren, hanem, hogy „Isten magyar népe legyen minél erősebb a katolikus hitben, a keresztény erkölcs sze-
Az ünnepi rendezvénysorozat folyamán Mindszenty mintegy 60000 zarándok elótt tartott szentmisét 1947. augusztus 15-én Esztergomban. Az egyházvezetố világos evangelizációs programot állitott a magyar katolikus közösség elé. Jól tudta ugyanis, hogy a támadások ellen a magyar egyház legnagyobb védelme az, ha belsóleg minél erósebb. Nem anyagiakban, nem birtokkal, nem gazdasági-pénzügyi téren, hanem, hogy „Isten magyar népe legyen minél erósebb a katolikus hitben, a keresztény erkölcs szerinti életben, a cselekvố szeretetben, az evangéliumi közösségben”. Evangelizációs programjában egy meróben új módszert alkalmazott: a személyes kapcsolat mozgósító, hitelesitố erejét vette igénybe. Járta az országot, közösségeket keresett fel, és mindenütt tíz-és százezrek hívták, várták és hallgatták tanitását. Hatalmas karizmatikus eró áradt belóle, s az ország nagy része spontán módon ót tekin-

tette a katolikus-keresztény magyarság hiteles képviselójének, akiben imponáló, vonzó módon volt érzékelhetố volt az egybefonódott katolikus hit és a magyar nemzettudat (Mészáros, 2005, 102-103. о.). 
rinti életben, a cselekvő szeretetben, az evangéliumi közösségben”. Evangelizációs programjában egy merőben új módszert alkalmazott: a személyes kapcsolat mozgósító, hitelesítő erejét vette igénybe. Járta az országot, közösségeket keresett fel, és mindenütt tíz- és százezrek hívták, várták és hallgatták tanítását. Hatalmas karizmatikus erő áradt belőle, s az ország nagy része spontán módon őt tekintette a katolikus-keresztény magyarság hiteles képviselőjének, akiben imponáló, vonzó módon volt érzékelhető volt az egybefonódott katolikus hit és a magyar nemzettudat (Mészáros, 2005, 102-103. o.).

A dolgozatunk homlokterében szereplő Csanádi Egyházmegyében 1948. május 22-23-án, az országos Mária-év keretében megrendezett Marosmenti Mária-napon például a bíborost vendégül fogadó Makó történetében addig ez volt a legnagyobb tömegdemonstráció. Sem előtte, sem utána ennyi ember nem gyült össze a város területén egy adott cél érdekében. Korabeli források alapján több tízezer ember látogatott el a rendezvényre (Medgyesi, 2000, 289. o.). A Mária-ünnep hevében, május 23-án vasárnap este még proklamáció-szerü táviratot is küldtek Makóról az egyházmegyei elöljárók Ortutay miniszternek: „Ortutay Gyula kultuszminiszter Úrnak, Budapest - A makói Mária-napon a csanádi egyházmegye minden részéröl összejött több mint harmincezer hívő, jórészben szülők, Isten adta jogukra támaszkodva egyhangú lelkesedéssel kimondták, hogy kérik, és határozottan kívánják miniszter úrtól a katolikus iskolák államosítása tervének elejtését. A Mária-napok rendezősége.” (Csepregi, 2012, 277. o.)

A sztálinisták 1948-ra az egyház-ügyet már csakis politikai szinten látták megoldhatónak. Mindszenty következetesen egyre keményebb magatartást tanúsított a kormányzattal szemben és kerülte a kompromisszumokat. Rákosi 1948. január 10-én az MKP funkcionáriusainak tartott értekezletén vázolta a következő időszakot:

„A demokrácia ez évi feladati között ott van az egyház és a népi köztársaság viszonyának rendezése. Meg kell szüntetni azt a tarthatatlan állapotot, hogy a magyar nép ellenségeinek zöme az egyházak, elsősorban a római katolikus egyház palástja mögé bújik. A fiatal magyar demokrácia három esztendőn keresztül mindent megtett arra, hogy a katolikus egyházat is bevonja a nemzet talpra állításának nagy munkájába. Meg kell állapítani, hogy siker nélkül. A magyar katolikus egyház vezetőinek többsége, Mindszenty Józseffel az élen még ma sem ismeri el a köztársaságot. Vissza kívánja állítani a régi úri nagybirtokot, ellenzi a hároméves tervet és a demokrácia minden egészséges kezdeményezését. A magyar demokrácia eddig minden problémát, mely elé a történelem állította, megoldott. Amikor napirendre tüzi, végezni fog azzal a reakcióval is, mely az egyház köntöse mögé bújik." (Gergely, 1985, 59-60. о.)

Majd június 10-én a pártfőtitkár ezt írta levelében a párizsi magyar nagykövetnek, Károlyi Mihálynak ${ }^{12}$ : „Hogy sor kerül-e Mindszenty letartóztatására, az természetesen politikai kérdés", vagyis nem a konkrét bünösségének volt függvénye, hogy eltávolítsák a hivatalából, vagy sem (Mészáros, 2005, 134. o.).

1948 júniusában a kommunisták egyesültek a szociáldemokratákkal, majd az Országház az egyházi iskolák államosításáról szóló törvényt elfogadta és törvényerőre emelte. Ezáltal az egyház elvesztette 3000 tanintézményét és 18000 pedagógus került állami státuszba. Nehézség adódott a többi közel 3000 szerzetes tanár elhelyezéséből, amelyet a klérus csak nagy gonddal, vagy némely állomáshelyeken egyáltalán nem tudott megoldani (Gergely, 1985, 69-71. o.).

1948 nyarára Mindszenty eltávolítását tekintette végső megoldásnak a rendszer. Céljuk a papság megtörése volt azzal a nyilvánvaló szándékkal, hogy a kléruson belüli, rendszerellenes vélemények hasztalanságát mutassák - hiszen ha a hatalom a hercegprímást meghurcolni képes, mit várhat a jövőben az egyház többi tisztségviselője? 
A hercegprímás elleni támadásokat ekkorra már nyíltan is vállalták. Révai József ${ }^{13}$, a párt fóideológusa az értelmiségnek tartott beszédében így fogalmazott a budapesti Sportcsarnokban 1948 nyarán:

„Az iskola kérdésében sem lehet antiklerikalizmussal vádolni a magyar demokráciát. Az iskolák államosításának kérdése csak demokráciánk fennállásának negyedik évében merült fel, míg például Lengyelországban ez azonnal bekövetkezett. Az államosítás problémája nem függetlenül merült fel a klerikális reakció politikai magatartásától. Az volt az előzménye, hogy a katolikus egyház legfelsőbb köreinek egy bizonyos szárnya kezdettől fogva mereven és élesen szembefordult a demokráciával és annak minden törekvésével. A helyzet kiéleződésében döntő szerepet játszott, hogy a katolikus egyház élén, Magyarországon Mindszenty esztergomi érsek áll. Mindszenty volt a fö akadálya annak, hogy bármiféle megértés, vagy közeledés történjék a katolikus egyház és a magyar demokrácia között, ő testesítette meg a magyar klérusban azt az irányzatot, amely a demokráciával mereven szembeállott." (Révai, 1948, 294. o.)

Az év nyarán, az 1948. június 3-i Pócspetri faluban történt gyilkosságot is a politika az egyház ellen használta fel. A település lakossága tüntetést rendezett az iskolák államosítása ellen a tanév végén. A falu központjában kialakult intézkedés közben az egyik rendőr halálosan megsebesítette magát, amivel megvádolták a helyi plébánost. Az újságokban ezt az ügyet is a „klerikális reakció” munkájának állították be, vagyis Rákosiék a sajtón keresztül rendőrgyilkosságot kreáltak a véletlen balesetből. A későbbi vizsgálatok során - kényszer alatt - Asztalon János plébános az esetet magára vállalta, bünösnek vallotta magát. Halálra ítélték, de végül kegyelmet, életfogytiglani börtönt kapott. Az üggyel „,csak” példát kívántak statuálni.

1948. november 19-én Zakar Andrást ${ }^{14}$, az érseki titkárt letartóztatták, így az esztergomi egyházi elöljáró előtt többé már nem volt kérdés, hogy hamarosan reá is sor kerül (Mindszenty, 1989, 225. o. alapján). A titkár letartóztatása után közvetlenül Mindszenty nyilatkozatot adott ki, hogy semmiféle összeesküvésben nem vett részt. Nem mond le érseki tisztségéről, nincs vallani valója és semmit sem ír alá. Ha netán megtenné, az az emberi test gyengeségének tudható be, amelyet eleve semmisnek nyilvánít - utalva arra, hogy netán akaratbénító szerekkel kívánják majd a vallatás folyamán befolyásolni. A nyilatkozatot elküldte Grősz József ${ }^{15}$ kalocsai érseknek, annak másolatát pedig a bécsi Pázmáneumba.

Utolsó felvonásként a bíborost közéleti személyiségek keresték fel a jobb belátás érdekében, amely küldöttségben Kodály Zoltán is helyet foglalt. Igaz, ő - a többi jelenlévővel ellentétben - viselkedésével is jelezte (Mindszenty, 1989) Mindszenty felé, hogy a tárgyalás tartalmával, evvel a politikai közjátékkal nem ért egyet. Ám az alkutól a bíboros elhatárolódott, elveihez hűen várta „,büntetését”, majd 1948. december 26-án letartóztatták. Meghurcoltatását személyesen Rákosi Mátyás koordinálta. Tárgyalása előtt az ÁVO székházában vallatták, kábítószerek alkalmazásával vették rá, hogy tegyen önmagára nézve terhelő vallomást. A perben 1949. február 8-án hirdettek ítéletet, életfogytiglani szabadságvesztéssel. Mindszenty később vallomását visszavonta, ám az igazságszolgáltatás ezt már figyelmen kívül hagyta.

Az 1949-es országgyülési választásokon a „felszalámizott” pártokból összevegyített Magyar Függetlenségi Népfront színeiben ténylegesen a kommunisták vették át az ország irányítását. Révai József így beszélt 1949 márciusában, még a választások előtt egy központi vezetőségi ülésen: 
„Formálisan még nálunk is vannak elemei a hatalom és vezetés megosztásának, hisz más pártok is kormányon vannak, koalíció van. De ténylegesen - elvtársak egyedül a munkásosztály van hatalmon, és egyedül a mi pártunk vezeti az államot. Kell-e bővebben fejtegetni, hogy valóban csak formális jelentősége van annak, hogy Dobi István és nem Rákosi elvtárs a miniszterelnök; hogy ténylegesen azokat a minisztériumokat is mi vezetjük, amelynek élén nem kommunista miniszterek állnak.” (Mészáros, 2004)

Az idézett ténymegállapítás dolgozatunk szempontjából különösen fontos. A Révai-féle politikai helyzetértékelés a kriptokommunista Ortutay karakterét rajzolja fel. Ortutay posztján 1947 tavaszától 1950 februárjáig regnált, nevéhez köthetők a legfőbb egyház elleni intézkedések: az iskolák 1948-as államosítása után a parlament 1949. augusztus 18-án megszavazta a Magyar Népköztársaság új alkotmányát, amelyben a köztársaság biztosította az állampolgárok lelkiismereti és vallásszabadságát, valamint a vallás szabad gyakorlását. A lelkiismereti szabadság biztosítása érdekében az egyházat a Népköztársaság különválasztotta az államtól. İgy alaptörvényi szinten történt meg a szeparáció. A következő lépés az volt, hogy a Sík Sándor-tanítvány minisztersége alatt az 1949-es tanévtől fakultatívvá tették a hitoktatást, így onnantól már a vallástanítást külön kellett kérelmezniük a szülöknek az iskolákban. Az agitátorok mellett sok intézményben a tanárok és igazgatók is tevékenyen részt vállaltak abban, hogy a szülök véleménye negatív irányba forduljon. Mindezek után, 1950. február elején Rákosi hívatta irodájába Ortutayt. A moszkovita ezt mondta a kultuszminiszternek: „Nézd, Gyula, barátsággal, bizalommal vagyunk irántad, de most egy időre a kardot visszatesszük a hüvelybe." (Mészáros, 2004, 31. o.) A minisztert félreállították, többé már nem volt szüksége rá a hatalomnak.

Az alkotmányozás után törvényerejü minisztertanácsi rendelet értesítette az egyházakat, hogy esküt kell tenniük az új alkotmányra. A katolikus püspöki konferencia Grösz József elnökletével azonban még időt szeretett volna nyerni, arra való hivatkozással, hogy meg kell várniuk a Vatikán beleegyezését. Vagyis a hivatalos együttmüködést, ha csak lehet, halasztani próbálták. Állam és egyház egymás felé közeledésébe további éket vert az 1950 tavaszán indult béke-kampány: a stockholmi békefelhíváshoz csatlakozva - amely az atomfegyver betiltását is célozta - a „Megvédjük a békét” mozgalom nyilatkozat aláírására kérte a papságot, amelyet neves baloldali értelmiségiek és múvészek is támogattak. A püspöki kar nyilatkozatban utasította el a program támogatását. Véleményük az volt, hogy a katolicizmus és a kereszténység eszmeiségében és hittételeiben a béke híve, annak őrzője. A béke üzenete rajtuk keresztül évszázadok óta eljut a hívekhez, ezért különféle politikai nyilatkozatok aláírása felesleges. Június 1-én az MDP a következő határozatot hozta:

„A klerikális reakció aknamunkája a népi demokrácia ellen az utóbbi hónapokban fokozódott. Ez összefügg: a.) az osztályharc élesedésével az országban; b.) az imperialista háborús uszítók fokozódó agresszivitásával. A szocializmus építésének politikája fokozza és élesíti a régi uralkodó osztályok maradványainak, valamint a kulákságnak az ellenállását. A klerikális reakció pedig ezeket támogatja a mezőgazdaság szocialista átszervezésével szemben. Ugyanakkor a klerikális reakció az imperialisták ötödik hadoszlopának szerepét játssza Magyarországon.” (Gergely, 1958, 89. о.)

A határozat külön kiemelte az egyházi reakció leleplezésének és a szerzetesrendek feloszlatásának szükségességét. A paraszti rétegek és az ifjúság megnyerése volt az MDP célja az „imperialista agitátorok” félreállításával. 
1950 nyarán az államhatalom két fordulóban gyakorolt nyomást az egyházra: 1950. június 9-én, valamint június 18-án razziákhoz hasonló rajtaütésekkel internálták a szerzetesrendeket. Ennek következtében 1950. augusztus 30-án az egyház kénytelen volt aláírni az egyezményt, amelyben rögzítették, hogy a püspöki kar tiltakozik a terv ellen, de tudomásul veszik a négy szerzetesrenden kívül a többi rend feloszlatását. Az egyház részéröl nyereségként könyvelhették el, hogy nyolc oktatási intézményt visszakaptak, és az állam 18 évre kötelezettséget vállalt az egyház pénzügyi támogatására. A rendtagok többsége kénytelen volt ezután illegálisan munkát vállalni (Mindszenty, 1989, 429. o.).

Az egyházat teljesen elszigetelték Rómától, a diplomáciai kapcsolatok, a kiutazások gyakorlatilag megszűntek. Róma elvi álláspontját ismerhette ugyan a püspöki kar, de konkrét politikai lépéseket egyedül kellett tennie a testületnek. Az egyre gyengébb lábakon álló klérus müködését nagyban befolyásolta a hatalom által megszervezett békepapi mozgalom. Az 1950-ben létrejött és 1956-ig aktívan müködő, államhatalmi irányítású, magánéleti és korábbi politikai cselekedet miatt zsarolhatóvá vált papokból verbuvált szervezet egyik célja az egyház kettészakítása volt. A békepapok (vagyis a kollaboráns lelkészek) az állami akaratnak engedelmeskedö, saját püspökeikkel szembehelyezkedő politikai álláspontot képviseltek.

Kitérőként, csak a szemléltetés érdekében a mozgalom müködéséhez fontos néhány adatot idézni: 1950-ben az országban 3583 aktív pap végezte hivatását, és az 1952-es béke világtalálkozóra készülve az akciót aláíró és legitimáló papok száma 3309 volt. A kiáltványt a hazai papság legnagyobb része tehát aláírta, de a szervezők a legtöbb alkalommal csak erőszakkal tudták szignálásra bírni a lelkipásztorokat (Bögre, 1998, 64. o.).

1951. május 19-én létrehozták az Állami Egyházügyi Hivatalt (ÁEH), és júniusban Grősz Józsefet az érseki palotában letartóztatták, egy újabb központi békeív aláírásának elhárítása miatt (Szabó, 2010; Balogh és Szabó, 2001). A vádak a Mindszenty-féle koncepciós per mintájára: államellenes összeesküvés, a legitimista restauráció elökészítése, kémkedés, valutaüzérkedés. A püspöki konferencia elnökét 15 év szabadságvesztésre ítélték. Majd Czapik Gyula ${ }^{16}$ egri érsek vezetésével a püspöki kar letette az esküt a kommunista alkotmányra. Ugyanebben az évben a 20. számú kormányrendelettel az állam visszavette a fökegyúri jogot, vagyis minden magasabb egyházi tisztség betöltését elözetes jóváhagyáshoz kötötte. Onnantól a klérus ténylegesen állami felügyelet alá tartozott. Kulcspozícióba az egyházon belül csak az kerülhetett, akiket az ÁEH megbízható embernek tartott.

Czapik érsek, mint a püspöki konferencia akkori elnöke, Mindszentyvel ellentétben kompromisszumkereső volt az állami vezetőkkel. Ez nem jelentette a rendszerhez való hüségét, csak egyszerüen nem akart börtönbe kerülni, amit a püspöki kar elött nyíltan meg is fogalmazott (Mindszenty, 1989, 406. o.).

1951 nyarától a plébánosoknak megküldött püspöki körlevelek tartalma és szellemisége új formát öltött. A megyei püspökök az aratás sikerességére, békekölcsönök jegyzésére, valamint gyüjtésekre buzdítottak. A körlevelekben kötelező volt a püspököknek a nagy vezéreket, Sztálint és Rákosit éltetni. Valóságos vallási karikatúrák voltak ezek a körlevelek - írja Mindszenty $(1989,430$. o.) visszaemlékezésében -, amelyeknek a misék végi felolvasására az állammal kötött egyezményre hivatkozva kényszerítették a plébánosokat. Szimbolikus erővel bírt az is, hogy a budapesti Regnum Marianum templomot 1951-ben porig romboltatta Rákosi, majd annak helyére szocialista dísztribün és Sztálin-szobor épült. A hívőkhöz intézett propaganda-hadjárat másik eleme az egyházi ünnepek részleges felszámolása volt. 1952-ben munkanappá nyilvánították karácsony másnapját, majd a következő évben a húsvét hétföt is.

1953-tól az „olvadás” jelei mutatkoztak állam és egyház fagyos kapcsolatában. Sztálin halála fordulatot hozott a magyar egyházpolitikában is. A miniszterelnök türelemre intett a papsággal szemben, elítélte az ÁEH túlzott adminisztratív, kényszerítő munkáját. 
Ennek köszönhető, hogy az év augusztusában hittan-pótbeíratásokat lehetett tartani, ami azt vonta maga után, hogy a jelentkezők száma 25 százalékkal magasabb volt, mint a megelőző időszakban. Mindez mellett a kongrua mértékét sem csökkentették, ahogyan azt előbb a Rákosi-kormány 1954-től előirányozta volna. Új jelenség volt továbbá, hogy több hitbuzgalmi egyesület is aktivizálódott (pl. Rózsafüzér Társulat, Oltáregyesület). A „,klerikális reakcióról” megfogyatkoztak a sajtóhírek, s a marxista propaganda is lekerült a vezércikkekből. A kormány pozitív lépései által a püspöki kar sem tiltakozott az ellen, hogy 1954 októberétől csatlakozzanak a Hazafias Népfronthoz. Czapik érsek végig békülékeny, kompromisszumokat kereső politikát folytatott. A konferencia ünnepi körlevéllel fordult például a hívekhez felszabadulásunk 10. évfordulóján. A levélben az újjáépítés eredményeit fogalmazták meg, amelyért a Jóisten mellett a munkások erőfeszítéseiért is köszönetet kell mondani. Méltatták továbbá az új Magyarország politikusainak érdemeit, és biztosították a híveket a püspöki kar béke melletti elköteleződéséről. A normalizálódás jele volt az is, hogy a püspöki kar kérésére engedélyezték Mindszenty és Grősz börtönbüntetésének enyhítését, házi őrizetbe kerültek (Gergely, 1985, 138. o. alapján).

1956-ban, Czapik halála után a börtönből kiszabadult Grősz érsek látta el a püspöki konferencia elnöki teendőit. Mindszenty bíborost felsőpetényi házi őrizetéből 1956. október 31-én - a forradalom napjaiban - kiszabadították és a budapesti prímási palotába szállították. A november 3-án elmondott beszédében az egyházi restaurációt tüzte ki célul. Ha egy pillanatra is, de Mindszenty visszatérésére esély látszott: úgy tünt, az egyház elfoglalhatja régóta nélkülözött társadalmi pozícióját. De november 4-től, Nagy Imre közbenjárásának köszönhetően, menekülve a szovjetek és az újjászülető diktatúra elől, a bíboros az USA nagykövetségének falai között élt hosszú évekig.

\section{A hitoktatás alakulása a Csanádi Egyházmegyében 1945 és 1956 között}

A Csanádi Egyházmegye a vizsgált időszakban (1945-1956) Magyarország délkeleti peremén helyezkedett el. ${ }^{17}$ A püspöki székhely Szegeden volt. Hívei száma 269227 fó volt 1945-ben, és 22480 taggal 213 hitbuzgalmi egyesület múködött. 237 pap összesen 57 plébánián látott el szolgálatot, az egyházmegyét 1944-től 1964-ig Dr. Hamvas Endre ${ }^{18}$ püspök vezette (Gergely, 1985, 229-233. o.). A csanádi püspökség két föesperesi kerületből állt, amelyek a „szegedi” és a „Maroson túli” nevet viselték. 1945-ben még a helyi klérus fö anyagi támaszát a Kopáncs mellett található püspöklelei birtok képezte. A terület nagysága 5018 hold volt, éves jövedelme több mint egymillió pengőt tett ki. Ezen kívül a székeskáptalan még összesen 455 hold földdel rendelkezett, de ezeket az állam a földosztáskor kisajátította (Pál, 2010, 411-412. o.).

A szovjet csapatok bevonulása elötti napokban a csanádi püspök és papsága félelemmel tekintett a jövő felé. Attól féltek, hogy a szovjetek bezárják a templomokat és betiltják a vallás gyakorlását. Meglepetésre azonban az egész egyházmegyében a szovjetek nagy tisztelettel viselkedtek a papsággal, és arra szólították fel őket, hogy háborítatlanul végezzék további papi munkájukat. A gazdasági élet beindulásával egyidejüleg - a szovjet katonai parancsnokság és az új városvezetés támogatásával - így a hitélet is minden törés nélkül beindulhatott, illetve folytatódhatott. A tanügyi beszámolók alapján az 1944/45-ös szemeszterek hitoktatás tekintetében a korábbi rend szerint zajlottak (Pál, 2010, 412. o.).

A tanév végén Dr. Hamvas Endre püspök levélben köszönte meg Dr. Halász Pál ${ }^{19}$ kanonoknak, kerületi esperesnek a folyó tanévi, egyházmegyei hitoktatási jelentést. A levél megemlékezik a hittanárok buzgóságáról. Az ifjúság szellemi és lelki múveltségének megalapozásához az elemi iskolai hitoktatás nagyban hozzájárult. Az egyházmegye a gyermekek szentáldozása mellett fontosnak tartotta az oktatás minőségét is felügyelni: 
„Nem elégedhetünk meg oly általános adatokkal, melyekből nem tünik ki a hivatalos tankönyvön kívül használt más könyvek címe, vagy mivolta, a diákmisék helye, a szívgárdisták ${ }^{20}$ száma, a szentségekhez járulók aránya ott. [...] A hitterjesztés gondolatának az [Jézus Szent Gyermeksége] egyesület révén való népszerüsítését és a [Kis Hitterjesztő] terjesztését az elemi iskolákban nagyon óhajtom. [...] Sajnálatos, hogy egyik-másik intézetben (piaristák, Klauzál Gábor Gimnázium² ${ }^{21}$ ) az évzárás előtt nem volt közös gyónás. A bérmálkozásról elmaradtak az isk. év elején számba veendők. Esetleg soron kívül megbérmálom őket. A kat. ifjúsági lapoknak, különösen a »Zászlónk«-nak, a hittanárok kevés figyelmet szentelnek. A piaristák hittanára jelenti is, hogy a »Zászlónk«-nak előfizetője nem volt. Ennek oka lehetett, hogy az intézet saját diáklappal kísérletezett. Nem az erők elforgácsolását jelenti-e ez is? [...] A kat. tanok, különösen a világnézeti kérdések tárgyalása közben törekedjünk az Üdvözítő isteni alakját és szóról-szóra idézett szavait is mentől jobban a tanítványok lelkébe vésni." 22

- írja a főpásztor. Tehát az Egyházmegye a katekézisen ${ }^{23}$ és a lexikális oktatáson túl még világnézeti kérdésekben is széles körültekintéssel kívánta elősegíteni a gyermekek lelki épülését.

Egy 14 oldalas összefoglaló is készült a szegedi iskolák 1944/45-ös hitoktatási tevékenységéröl. ${ }^{24} \mathrm{~A}$ hittanórák rendben folytak a háborús viszontagságok ellenére, a diákok közös szentmiséken vettek részt. A gyermekek a plébániák által összeállított imádságos könyvekből is tanulhattak. Tanév elején és végén közös szentgyónás és áldozás volt az iskolákban. Az iskolai hitoktatók mindenhol figyelemmel követték az Actio Catholica felhívásait, és mindegyik iskolában müködött Szív Gárda. A felmérésben megjegyzés szerepel, hogy a hitoktatók kapcsolata lehetne még szorosabb a szülőkkel.

A papok minden igyekezetükkel megpróbálták a fiatalságot az egyház keretei között tartani. Ennek egyik jele volt, hogy a SZEB „bársonyos politikájának” ellenére 1945 áprilisában a népbírósági felelősségre vonások az egyházmegyét is elérték. Balogh János jezsuita főiskolai tanárt, Karácsonyi Guidó ${ }^{25}$ somogyitelepi plébánost, Gimes Gyula belvárosi segédlelkészt, Dr. Balogh Ányos premontrei szerzetest, volt tankerületi föigazgatót „múltbeli és jelenbeli szovjet és kommunista ellenes megnyilatkozások miatt” letartóztatták. A püspök papjai érdekében a helyi hatóságoktól kezdve a legfelsőbb hatósági szervekig mindenütt segítséget kért, és ennek eredményeként, néhány havi fogházbüntetés után, az elítéltek szabadlábra kerültek (Pál, 2010, 413. o.).

Az 1945/46-os tanév jelentéseiből még kiolvashatók az előző tanév jellemzői. Így például az egyházi személyek külön javadalmazásban is részesültek munkájukért. Saját jegyzeteik mellett a római katolikus katekizmust, a Bibliai történelem, a Római katolikus szertartástan és a Katolikus történelem tankönyveket használták pedagógiai útmutatóként. A tanárok bibliai témájú képeket használtak szemléltetőként, és az egyház által minden iskolának elöírt Szent vagy, Uram! címü imádságoskönyvből tanultak az elemisták. ${ }^{26}$ A tanulók osztályzatokat kaptak tanáraiktól, ünnepekkor és vasárnaponként szentmiséket látogattak, szentgyónásban és áldozásban részesültek, majd külön „exhortatio”-kat ${ }^{27}$ hallgattak. Hittanári felügyelettel közös lelki és vallásgyakorlatokon vettek részt. Általánosan jellemző, hogy az iskolába járók vallási magatartása kielégítő volt.

Az 1946/47-es tanévröl hasonló beszámolók készültek, de az átalakulás jelei megmutatkoztak. Az egyik plébániai beszámolóban például Kiss Ferenc káplán - a makói gr. Klebelsberg Kunó római katolikus fiúiskola vallástanára - azt közölte jelentésében, hogy az ifjúság a kötelezőn kívül a szentségekhez már csak szórványosan járt. Külön kiemelte, hogy nem tapasztalt vallásellenes megnyilatkozásokat Makón. ${ }^{28}$ Ebből arra következtethetünk, hogy az egyházmegye más területein történtek ilyen esetek, vagy legalábbis a 
plébániáknak erre külön ki kellett térniük jelentéseikben, hogy a püspökség felmérje a közhangulatot.

Ekkorra már hittankönyv-hiány lépett fel az egyházmegyében. Az iskolákban érzékelhető zavarodottságról is tudósítottak a beszámolók. Az oktatási rendszer átalakulása miatt „eltolódások” voltak tapasztalhatók: az alapfokú osztályok száma megnövekedett, a középfokúaké csökkent. Egyes hittanárok óráinak száma megduzzadt, másoké pedig összevonásra került. A jelentés végén a tanulók lelki gondozásának alaposabbá tételére vonatkozó felszólítás áll.

1946. szeptember 21-én látogatott először Mindszenty hercegprímási minőségében Szegedre, ennek apropóját az első csanádi püspök halálának 900. évfordulójára szervezett ünnepség adta. Hamvas püspök a bíborost mint korunk Gellért püspökét üdvözölte, és kérte, hogy - Gellért püspökhöz hasonlóan - mentse meg az országot a további zürzavartól, a kereszténységet pedig a pusztulástól. Az ünnepségsorozaton Grősz József kalocsai és Czapik Gyula egri érsek is részt vett (Pál, 2010, 415. o.).

Ennek a tanévnek volt az emlékezetes eseménye, hogy a kommunisták nyomására a hivatalosan FKGP-tag, valójában „kriptokommunista” Ortutay Gyula kultuszminiszter javasolta a fakultatív hitoktatásra való áttérést. Tavasszal megindultak az országos tiltakozó hullámok, amelyek egyik legnagyobbika Szegeden történt. ${ }^{29}$ Talán nem túlzás állítani, hogy a szegedi események is segítették a napirendröl levételét a választható hitoktatás bevezetésének. Rákosiék akciójának célja az lehetett, hogy a kisgazdákat ezzel is amortizálni tudják a politikai palettán, és hogy a hazai vallásos réteget tesztelni tudják. Kevés késéssel azonban mégis bevezették a fakultatív hitoktatást.

A négy koalíciós párt 1947. március 5-én elfogadta a fakultatív hitoktatásról szóló határozatot: „Az 1946. I. tc-ben biztosított lelkiismereti és vallásszabadság elvének megfelelően, az iskolai vallásoktatást fakultatívvá kell tenni. Minden szülőnek meggyőződésétől és szabad elhatározásától függ, vajon gyermekét kívánja-e vallásoktatásban részesíteni vagy sem.” (Mészáros, 2004, 6. o.) Március 12-én a püspöki kar tiltakozó körlevelet adott ki, ugyanakkor a sajtóban hatalmas kampány indult a jogszabály bevezetése érdekében (Mészáros, 2004, 6-7. o.). Március 19-én és a következő napokban tiltakozó megmozdulások indultak Szegeden. Az első nap délelőttjén a középiskolák szüneteiben indult a szervezkedés. A kiindulópont az egykori Klauzál Gábor Gimnázium volt: a nagyszünetben a diákság kiözönlött az utcára, és csatlakozott hozzájuk a szomszédos Baross Gábor Gimnázium ${ }^{30}$ tanulóifjúsága. A Dóm téren csoportosultak a többi szegedi középiskola fiataljaival, egyetemistákkal, főiskolásokkal tömeget alkotva, és skandálták: „Hittanórát akarunk!”; „Le a vallásellenes köztársasággal!” (Bálint, 2002) Rendörök támadtak a tüntetőkre és brutális ütlegelésbe kezdtek. A karhatalom tömegoszlatása több-kevesebb sikerrel járt, a diákok egy része ugyanis bemenekült a Fogadalmi templomba, más része szétszéledt a környező utcákon. A rendőröknek sikerült néhány diákot kiemelniük és előállítani. Alig vonultak el a rendőrök, a templomba menekült diákok újra csoportosulni kezdtek, majd elindultak a Stefánia sétányra a tankerületi föigazgatóhoz, Janson Vilmoshoz. A tanulók követelték a hitoktatással kapcsolatos rendelkezés visszavonását és azt, hogy a föigazgató vegye fel a kapcsolatot a rendőrséggel, és járjon el őrizetbe vett társaik szabadításáért. Az óvatos igazgatótól meggyőző választ nem kaptak, ezért a Kossuth Lajos sugárútra vonultak, a rendőrpalotához. A városi vezetők lassan eszmélni kezdtek, és a rendőrség előtt megjelentek a párt helyi aktivistái, a baloldali ifjúsági szervezetek vezetöi, és erélyesen követelték, hogy a tüntetést haladéktalanul függesszék fel, a föigazgató rendeljen el vizsgálatot az ügyben, és vonják felelősségre az iskolák vezetőit is. Dénes Leó polgármester véleménye az volt, hogy „Lényegesen változtatna Szeged politikai arculatán, ha a tankerületi föigazgató helyett kommunistát lehetne kinevezni." (Bálint, 2002). A Kossuth Lajos sugárúton kisebb-nagyobb csoportokban távozó diákok közé ekkor már beférkőztek az államvédelmi nyomozók is, figyelték a hangadókat. 
Az esemény híre futótúzként terjedt országszerte. A kommunista vezetés alatt álló helyi sajtó azonnal élénken reagált a történésekre. A Délmagyarország napilap jobboldali kalandorkodásról, fasiszta megmozdulásról, demokrácia elleni támadásról tudósított, a Szabadságpárt helyi agitátorait megnevezve felbujtóként (Bálint, 2002). A diáktüntetés ugyanis ürügyet adott ahhoz, hogy a korábbinál erőteljesebb támadás induljon a Szabadságpárt ellen, amely szervezet komoly esélyekkel indulhatott volna az év augusztusában megrendezett országgyülési választásokon. (Rákosiék egy hónappal a voksolás előtt kizárták őket, a választási törvénnyel ellehetetlenítették indulásukat.) Másnap, március 20-án még nagyobb demonstráció indult. Reggel a város diáksága a Széchenyi téren gyülekezett, majd átvonult a Dómhoz. A tér bejáratait teherautókon és gyalogosan érkező helyi szakszervezeti aktivisták állták el tömegével, mögöttük készenlétben a rendörök és az államvédelmi osztály polgári ruhás tisztjei. Felszólították a tér elhagyására a fiatalokat, de a területről csak rajtuk keresztül lehetett volna távozni. A Komócsin Mihály ${ }^{31}$ helyi szakszervezeti vezető által delegált teherautósok a tömegbe hajtottak. Aki tudott, a templomba menekült, aki ott maradt, azt ütlegelték. A rohambrigádok szétverték a tüntetést. Amíg a veröemberek dolgukat végezték a templom mellett, addig két külön csoport is akcióba lendült. Az egyik felkereste Janson Vilmos tankerületi vezetőt, házkutatást tartottak, majd előterjesztették kifogásukat, hogy kevés a munkás- és parasztszármazású diák a szegedi oktatási intézményekben, valamint kérik, hogy a diákmegmozdulás szervezőit azonnal távolítsák el az ország összes tanintézményéből. A delegáció több tagja ezután öntudatos, harcos munkásokhoz illően a helyszínen elénekelte az internacionálét. A másik delegáció a patinás belvárosi Tisza Szállóhoz vonult, a Szabadságpárt helyi szervezetének irodájába. Öket a rendőrök mellett már újságírók is kísérték. A párt tagjait felszólították, hogy tartózkodjanak a diákság politikai célokra történő felhasználásától, átkutatták az irodát, majd letépték a párt tábláit, plakátjait, és több aktivistát őrizetbe vettek. A tüntetés brutális szétverése fölborzolta Szeged lakosságának hangulatát. Sokan hitték, hogy március 20-án délután véget értek a megmozdulások, ám az esti órákban az Ady-téren folytatódtak. A több száz fös tömeg a rendőrpalotához indult, ahol követelték a letartóztatottak szabadon engedését. Válaszul erre a rendőrség újra szétverte a tömeget, újabb kiemelések és letartóztatások történtek. Ugyanebben az időben a Dóm téren is gyülekeztek diákok, akik a brigádok megjelenése után bemenekültek a Fogadalmi templomba. Másnap a helyi sajtóban az akkorra már politikailag erősen támadott Janson Vilmos fölhívást tett közzé, elítélte a tüntetéseket, és magyarázni próbálta a fakultatív hitoktatás mibenlétét. Még ezen a napon, március 21-én is feszült volt a hangulat. Délután a Dugonics téren ismét gyülekezni kezdtek a fiatalok, akikhez már felnőttek is csatlakoztak, de a rendőrség keményen közbelépett. A következmények nem maradtak el: a márciusi szegedi diákmegmozdulások folytán több embert internáltak. Az állam biztonságára, a társadalmi békére s a közbiztonságra aggályos, gyanús személyeknek lettek titulálva. A tüntetés miatt „,izgatás” vádjával Szélpál István és Kovács Józsefné tanárokat népbíróság elé állították. ${ }^{32}$ Janson Vilmos tankerületi igazgatót rendkívüli jelleggel szabadságolták. A MADISZ írásban követelte leváltását, a Délmagyarország napilap is politikai kiáltványokat fogalmazott meg. Egy hónapra rá kevésbé exponált pozícióba, a budapesti tankerületi igazgatóságra, vezető helyettesi beosztásba került. ${ }^{33}$ Április 2-án Hamvas Endre csanádi püspök pedig eredménytelenül kérte a kultuszminisztertöl az internált szegedi fiatalok szabadon bocsátását és tanulmányaik folytatásának lehetőségét (Bálint, 2002).

Március 21-én a kulturális tárca vezetője bizottságot rendelt Szegedre, felelősöket keresni és kiértékelni a helyzetet. Megrovásban részesítette a tankerületet, és rendkívüli szülői értekezletek összehívására utasított. A jegyzőkönyv szerint a minisztériumi alkalmazottak gyors eredménnyel jártak. A szegedi állami leánygimnázium ${ }^{34}$ volt a diákmegmozdulások bölcsője. Az iskola három tanárát felelősségre vonták, az igazgatót azonnali 
hatállyal menesztették. A következő napokban március 22-i keltezéssel a tankerületi főigazgató az illetékessége alá tartozó összes szegedi iskola igazgatóságának írásban megküldte a tárcavezető miniszter telefonon küldött üzenetét: „A szegedi diáktüntetéssel kapcsolatban kiküldött fegyelmi bizottság jelentéséből megállapítottam, hogy a szegedi középiskolák igazgatói és tanári testülete nem tanúsított kellö erélyt és határozottságot a diáktüntetések megakadályozásában [...] feltétlenül elítélendő határozatlan magatartásukért nagyfokú rosszallásomat fejezem ki." (Mészáros, 2004, 8. o.)

A tanév végén a szülők részére a vármegye minden intézményében értekezletet hívtak össze a felsőbb utasításnak megfelelően. Az igazgatók nyugtatni próbálták a jelenlévőket, és kivétel nélkül a katolikus papokat nevezték meg a káosz kirobbantóinak. Minden alkalommal Ortutaynak a Köznevelés folyóiratban, április 1-én megjelent A magyar köznevelés kérdései címü publikációját jelölték meg irányadónak, amelyekből a szülöknek részleteket is felolvastak. ${ }^{35}$ A gyüléseken elhangzottakhoz érdemes áttekintenünk az 1947-ben megjelent újságot, kiemelve annak főbb gondolatait.

Vezércikkében Ortutay a demokrácia ellenségeinek állítja be a klérust, illetve baloldali és szabadelvű gondolatokkal próbálja tisztázni a közérdeklődésbe került oktatáspolitikai kérdéseket. Olvasva a folyóiratot, a cikk írójának inkább a félrevezetettségéről és naivitásáról győződhetünk meg, mintsem rosszhiszemüségéről. A sorokból kiolvasható a Moszkvából irányított kurzus kapkodása is, hiszen mindvégig a más kérdésekben fö ellenségnek beállított „imperialista” nagyhatalmakat hozza fel követendő oktatásügyi példának. Az ország szovjetizálódásának folyamatát ismerve arra juthatunk, hogy Ortutay csak báb és eszköz volt a Rákosi-diktatúra kezében, a későbbi történések ugyanis ellentétben álltak az 1947. április 1-én az újságban megjelentekkel.

Írását kifejtendő kérdéssel kezdi: „Mire törekszik a koalíciós kormányzat?” A kormány a nevelés által adott kulturális kincseket, a müveltségnek európai és magyar eredményeit nem akarja a jövőben egy kis osztály kizárólagos tulajdonává tenni - summázza. Hangsúlyozza: az értelmiségnek a dolgozó nép értelmiségévé kell válnia. Vállalnia kell azt a feladatot, hogy a munkás- és parasztosztály kiszolgálója legyen. A müveltség nem valami különálló, nehezen elérhető és kevesek számára biztosított kiváltság. Szükséges, hogy a müveltség minden magyar dolgozó embernek belső tulajdona, saját természetének legföbb irányítója legyen. A jövőben nem fordulhat elö, hogy kiváltságos emberek tulajdona legyen, egy arisztokratikus, zártkörü szalon - utal az egyház évszázadok óta kitüntetett társadalmi helyzetére. A több oldalas írás második részében a kialakult helyzetre reagál:

„A szabad vallásoktatás kérdésében szervezett rágalomhadjárat indult az országban. Olyanokat állítanak, mintha ez a szabad vallásoktatás vallás elleni küzdelem lenne, sőt egyenesen a vallásoktatás és gyakorlás eltörlésére irányulna. Mi egyaránt tiszteletben kívánjuk tartani mind a vallásszabadság, mind pedig a lelkiismereti szabadság nagy gondolatát. A magyar demokrácia nem türheti el, hogy bármilyen ürüggyel a jobboldal újra szervezkedjék és a demokrácia ellen felvonultasson lappangó jobboldali erőket." 36

A cikk végén nyugat-európai és amerikai példákat hoz a fakultatív hitoktatás sikeres bevezetésére. Az USA, Anglia, Argentína, Belgium és Brazília oktatáspolitikájának bemutatásával próbálja ellensúlyozni a szülők félelmeit. ${ }^{37}$ Ezekkel a sorokkal zárja a Köznevelésben megjelent írását Ortutay, amelyekkel a szülői értekezleteken is apelláltak az iskolaigazgatók 1947 tavaszán.

Az 1947/48-as tanévben a Janson Vilmos helyébe kerülő új tankerületi föigazgató, Dr. Páti Ferenc intézett határozott hangú körlevelet a vármegye iskolavezetőihez. Páti levelének fejlécére ez került, a súlyosbítás érdekében három felkiáltójellel: „Bizalmas!!!” 
Az igazgatókat nyomatékosan felszólítja, hogy az iskolák államosításával kapcsolatban felmerült „hamis hírek és félrevezetések” kapcsán törekedjenek az iskolai és ifjúsági élet minden mozzanatát megismerni a környezetükben. Továbbá:

„Ahol aggasztó jelenségeket tapasztalunk, melyek az ifjúságot meggondolatlan cselekedetekre ragadhatják, vegyük igénybe a megelőzés, a lelki ráhatás minden eszközét. [...] Igazgató Úr figyelje, hogy a nevelöi kar minden tagja hivatásának magaslatán áll-e ebben a vonatkozásban. [...] Végül ismételten felhívom figyelmét, hogy az iskola életében megmutatkozó minden aggasztó jelenségről azonnal tájékoztasson."

Páti a leveléhez mellékelt egy propagandaanyagot is, amely az iskolák államosításával foglalkozik. Az igazgatók figyelmébe ajánlotta a 10 pontba foglalt „,sorvezetőt”, amely alapján felkészültebben tudnak majd reagálni a támadásokra. Az összefoglaló szerint életképtelenek és hiányos alapmúveltséget tudnak biztosítani a felekezeti iskolák. A falusi iskoláknál magasabb színvonalúak lesznek az állami tanintézmények a jövőben. Azok az államosítás után kétszázezer parasztifjú számára fogják megnyitni az utat a magasabb iskolák felé, és biztosítják majd a pályaválasztás szabadságát.

A felekezeti iskolák elhanyagolt állapotban vannak - olvasható -, továbbá az egyházi oktatással ellentétben az állami oktatás ingyenes lesz, a tankönyvekért nem kell majd fizetni. Gondoskodni fognak a tanerö-szükségletről, nem kell összevont osztályokat müködtetni, ahol több évfolyam tanul egyszerre. Az anyag érdekessége, hogy ígéretet tesz az államosítás utáni hitoktatás kötelező érvényére. ${ }^{38}$

Az iskolák állami kézbe vételekor az egyházmegyében összesen 31 felekezeti általános iskolát államosítottak 290 tanítóval, 182 tanteremmel és 7617 tanulóval. ${ }^{39}$

Az 1948/49-es tanév elején Hamvas Endre fópásztori szózatában ${ }^{40}$ kiemeli a hitoktatás fontosságát:

„A hitoktatást iskoláink államosítása nem érintette. Gyermekeink lelke és vallásoktatási nevelése érdekében e lehetőség lelkiismeretesen kihasználandó. Hitoktatási óráinkat adjuk le pontosan, és ha a káplán hittanórákat tart, abban a plébános ne hagyja öt zavarni temetés vagy betegellátás címén, hanem ezen funkciókat tegyék át tervszerüen olyan órákra, amikor hittan nincs."

Hamvas idézett körlevelében még további óvatosságra intette lelkipásztorait:

„A tanításban legyünk okosak. Ne engedjük magunkat olyan nyilatkozatra elragadtatni, amely akár valóságos, akár félremagyarázható értelemben kifogásra okot adhat. Természetesen az egyház tanaiból azért nem hagyhatunk el egy iótát, vagy vesszőt sem. Ezt bizonyára nem is kívánja tölünk senki sem.”

Tehát ebben a tanévben még bizakodva nézett a jövőbe a szegedi fópásztor ${ }^{41}$, akit a sajtó onnantól már sorozatosan támadott. A Csanádmegye címü politikai napilap 1948. június 6-i száma erről cikkezett: „A csanádmegyei ${ }^{42}$ katolikus papoknak tilos nyilatkozni, cikket írni, politikai gyülésen felszólalni és pártoknak a kérésére misézni." 43 Az újságíró Hamvas püspököt célozza:

„Dr. Hamvas Endre csanádi megyéspüspök papjainak a napokban körlevelet küldött ki, amelyben rendkívül érdekes utasításokat ad számukra. A levél, amely litografált ${ }^{44}$, de valamennyi külön-külön a püspök által tintával aláírt 1300-1948. számot viseli. A levél bevezető részében utal arra a püspök, hogy az utóbbi időben 
papok és egyházi személyek részéről több nyilatkozat hangzott el és ezzel kapcsolatban szükségesnek tartja a következő rendelkezéseket kibocsátani: »Megtiltom (a papoknak) mindenféle nyilatkozatnak a tételét politikai pártok vagy lapok felé. Ugyancsak megtiltom, hogy bárki cikket írjon előzetes cenzúra nélkül, vagy politikai gyülésen felszólaljon! Nem engedhető meg továbbá a pártok által kért külön szentmisék tartása. Ha misére akarnak jönni a pártok, jöjjenek a rendes idöben tartandó misére. « Az utóbbi időben egyre több és több nyilatkozat hangzott el - valóban a papok és egyházi személyek részéről, akik nyilatkozataikban egyre erőteljesebbé váló hangon tettek hitet a demokrácia mellett. Ez a rendelkezés úgy látszik ezt a megnyilatkozást és ezt az állásfoglalást akarja lehetetlenné tenni. Bizonyos mértékben a gyengeség jele is egy ilyen rendelkezésnek a kiadása, mert bele akarja fojtani a szót egy ilyen utasítás azokba, akik a demokrácia mellett állnak, erről bizonyságot akarnak tenni, és dolgozni akarnak érte. Különösen figyelemreméltó az utasításnak az a része, amely megtiltja a pártok által kért szentmisék szolgáltatását. Úgy emlékezünk, ilyen kéréssel a pártok akkor fordultak az egyes lelkészekhez, amikor különleges ünnepe volt a község lakosságának, a népnek. Ilyen alkalmak voltak a május 1., vagy azt megelőzően a »Miénk a Föld « ünnepség, hogy csak egyet-kettőt említsünk meg. Bizonyos, hogy ez a két ünnep, a dolgozók ünnepe és a földhöz jutott nincstelen parasztság ünnepe, megérdemlik azt, hogy az egész ország, tehát az egyház is a maga módján velük együtt ünnepeljen, ezért nem értjük miért volt szükség ilyen rendelkezés kiadására, amely a jövőben ilyen szentmisék megtartását lehetetlenné teszi. Úgy érezzük, hogy a pártok, amikor szentmisével is akartak ünnepelni, éppen azt bizonyították: ragaszkodnak a valláshoz és az egyházzal együtt akarnak haladni a demokrácia útján. Különösebb kommentár, többet ez a püspöki utasítás nem kíván." 45

A fent idézett cikk erősen befolyásolhatta azon szülőket is, akik a következő szeptemberben hittanra szerették volna beíratni gyermekeiket. A szerkesztő által megfogalmazottaknak nincs igazságtartalmuk. A jelzett körlevél nem található meg az egyházmegye levéltárában, pedig a hivatal minden föpásztor által kiadott rendeletet archivált a múlt század elejétől kezdődően egészen napjainkig. Egyetlen püspöki rendeletet lehet találni, amely 1948-ból származik, és valóban összefüggésbe hozható a lelkipásztorok ilyen jellegü rendszabályozásával, és ami eljutott a papokhoz. De tartalma, hangvétele távol áll a sajtóban leírtaktól. Szöveghủen így szól a szabályzat:

„Az Egyházi Törvénykönyv 2344. kánonja kimondja a következőket: »Azt, aki a Római Pápát, az Anyaszentegyház bíborosát, a Római Pápa követét, a Római Szent Kongregációkat, az Apostoli Szentszék Törvényszékeit és ezeknek főbb tisztviselőit, továbbá a saját főpásztorát nyilvánosan újságokban, nyilvános beszédekben, vagy iratokban akár közvetve, akár közvetlenül jogtalanságokkal illeti, továbbá ezeknek tettei, határozatai, döntései és ítéletei ellen visszavonást vagy gyülöletet szít, a fópásztor nemcsak a fél kérésére, hanem hivatalból kötelezze még egyházi büntetések kiszabásával is elégtétel adására. Továbbá a bünének és az okozott botránynak arányában más megfelelő büntetéssel és elégtétel-kirovással is sújtsa az illetőt.« Sajnos, manapság ilyen támadások sajtóban igen sokszor álnéven vagy név megadása nélkül történnek. Ugyanakkor pedig az érdekelteknek nem adatik meg a lehetőség arra, hogy ezen támadások ellen a kérdések másik oldalának megvilágításával és a téves állítások megcáfolásával válaszoltassanak. Helyesen járunk el tehát, ha adott esetben, a most idézett egyházi törvényeinknek következményeire szeretettel figyelmeztetjük a törvény ellen vétöket." ${ }^{46}$ 
Az egyház elleni provokációkat még jobban erősítette hasonló, igazság nélküli újságcikkekkel a hatalom. A helyben legolvasottabb, közhangulatot formáló Délmagyarország napilap például, támadva a csanádi püspököt, ezt írta 1948. május 28-i vezércikkében:

„Letörjük a klerikális reakciót - mondotta nagyjelentőségü beszédében Révai József. - [...] Ha a plébánosok, szerzetesek, esperesek ilyen módon követik a demokrácia elleni uszitásban a magyar külpolitika aláaknázásában, soviniszta uszitásban a hercegprímás példáját, akkor nem lehet azon sem csodálkozni, hogy a csanádi püspök Hamvas Endre Makón május 23-án módositását rendelte el annak a régi gyönyörü egyházi éneknek, amely Magyarországról, édes hazánkról szól. Kiadta a rendelkezést, hogy ezután ezt az éneket ne így énekeljék, hogy »Magyarországról, édes hazánkról« hanem így: »Magyarországról, romlott hazánkról«."47

Az államosítás után az állam ellenőrizni kívánta a hitoktatók kinevezését és utat nyitott a hittanórák megtartásának akadályozására. Csak megfelelő tanulólétszámmal voltak megtarthatóak a lelkiségi foglalkozások. Egyre több helyen lehetetlen volt hittanórát tartani a kevés jelentkező miatt, köszönhetően az állam vallás- és egyházellenes propagandájának. Dr. Hamvas Endre 1948. évi 2152. számú püspöki körlevelében Ortutay Gyula vallás- és közoktatásügyi minisztert a püspököknek megküldött leveléböl idézi:

„A hittan kötelező tantárgyi jellegét az 1948. évi XXXIII. t. c. nem érintette és így a hit-, és erkölcstan az államosított volt felekezeti iskolákban továbbra is kötelező tantárgyként szerepel. [...] Kérem aziránti előterjesztését, hogy az államosítás következtében mely városokban és községekben, illetve mely iskoláknál lesz feltétlenül szükséges új önálló hitoktatói állások szervezése? Hangsúlyozom, hogy önálló hitoktatói állások szervezésére, illetve államsegélyes állássá való elismerésére csak akkor kerülhet sor, hogyha az illetö iskolában, vagy községben az elöírt tanulólétszám is meglesz. [...] Az óraadó hitoktató személyét az egyházi hatóság jóváhagyásomtól feltételezetten jelöli ki. A fentieket azzal hozom a Fötisztelendő Egyházmegyei Hivatal tudomására, hogy az óraadó hitoktató kijelölése iránt sürgősen intézkedni, az idevonatkozó kimutatásokat alárendelt hatóságaitól bekérni és hozzám mielőbb felterjeszkedni szíveskedjék." 48

Az 1948/49-es tanév elejére az egyházmegyei vezetés hitoktatói értekezlet hívott össze a Szemináriumba ${ }^{49}$. A megbeszélést ${ }^{50}$ Hamvas püspök vezette, aki felszólalásban hangsúlyozta, hogy az aktuális politikai helyzet miatt a hitoktatás különös jelentőséggel bír. „Az értekezletek innentől még fontosabbá válnak, mint előtte." ${ }^{51}$ A főpásztor attól a tanévtől még több hitoktatót kívánt kinevezni. Havass Géza ${ }^{52}$ hittanár és püspöki titkár az ifjúsági szentbeszédekre vonatkozóan tájékoztatta az értekezletet. Véleménye szerint: „apologétikus beszédek volnának szükségesek főként Istenről és a lélekről a mind nagyobb tért hódító materiálizmussal szemben". A püspök erre jelezte, hogy a szentbeszédek tartalmát nem kívánja elöre meghatározni, hanem azt tanácsolta, hogy az ifjúsági szónokok beszéljék meg egymással, hogy az egész iskolai évben miről kívánnak beszélni. A megjelentek az egyesületek ügyét is megtárgyalták. Együttesen állapították meg, hogy az iskolai kongregációkat, a vallásos egyesületeket fenn kell tartani, mert hasznos a müködésük.

A tanulók lelkesen kapcsolódnak be a munkákba, csak a továbbiakban több körültekintéssel kell lenniük a vezetöknek. Hamvas Endre a megbeszélésen külön leszögezte, hogy a hitoktatók semmilyen körülmények között nem vállalhatnak szerepet az úttörők, vagy más népi demokratikus egyesület munkájában. Merksz Elemér ${ }^{53}$ hitoktatói beszámolóban lesújtóan nyilatkozott a kialakuló úttörőmozgalomról a gyülésen: a Szívgárda életét mindenütt akadályozzák. Az igazgatók visszatartják a gárda életét, az úttörők hivatalos 
vezetőinek utasításaira hivatkozva nem engedélyezik a müködésüket. A hitoktatókat igyekeznek befeketíteni az úttörő mozgalmárok gyermekein keresztül, akiket különféle hamis vádak állítására késztetnek. ${ }^{54}$

1949. január 10-én, Mindszenty letartóztatása után a püspöki konferencia szózattal fordult a hívekhez, amelyet minden templomban a csanádi papok is felolvastak a soron következő vasárnap:

„Anyaszentegyházunk jelenlegi szomorú és gondterhes helyzetében szívünk meleg szeretetével és főpásztori tisztünk felelősségteljes gondosságával szólunk hozzátok! [...] Az Egyház és Állam viszonyának közismert állapota nem engedi, hogy önmagunk járjunk csak el, hanem parancsadóan megköveteli, hogy Egyházunk törvényei szerint az Apostoli Szentszékkel egyetértésben cselekedjünk. Ezeknek tudatában megkívánjuk tőletek, hogy magatartásotokat szabjátok az Egyház törvényeihez és annak fegyelmét hüségesen tartsátok meg. Általában tartózkodjatok minden felforgató törekvéstöl.

A megpróbáltatás és szenvedés idején kell kimutatnunk Istenbe vetett hitünket, reményünket és szeretetünket. [...]"55

- írja a püspöki kar, amit felolvastak az egyházmegye minden templomában.

A tárgyalt tanítási időszak végén, májusban még Dr. Marcell Mihály pápai prelátus, a hittanárok országos egyesületének elnöke 1949. június 21-23. dátummal országos hittanári konferenciát hívott össze Budapestre. Majd néhány héttel később, június 8-án levél érkezett az egyházmegyei püspöki hivatalba: „A június 21-23-ra hitoktatói értekezletet technikai, anyagi nehézségek miatt bizonytalan időre elhalasztjuk." ${ }^{\prime 56}$ Ez időtől nem találunk adatot a hittanárok országos egyesületének munkájáról. A katolikus ifjúság oktatásának, nevelésének szervezeti működését és hátterét a hatalom 1949 nyarára végérvényesen elapasztotta.

Az 1949/50-es tanév októberében, a fakultatív hitoktatás bevezetése után Hamvas Endre egyházmegyei hitoktatói értekezletet hívott össze a Szeged-Belvárosi Egyházközség irodájában. A találkozó célját így határozta meg: „tájékozódás a hitoktatásról és instrukció nyújtás" ${ }^{57}$ A beszámoló szerint minden iskolában elindult a hitoktatás, kivéve három iskolát, ahol a kevés jelentkező miatt nem tudtak hitoktatókat kinevezni. Hamvas Endre kérése volt, hogy a hitoktatók felügyeljenek a szentmisék alatt, akadályozzák meg, hogy a gyerekek a szentmise befejezése előtt távozzanak a templomokból. Tárgyalták a „hittankönyvek ügyét” is, valamint az új hitoktatási segédletek terjesztésére is napokon belül engedélyt kap az egyházmegye a kultuszminisztertől, így hamarosan nyomdába kerülhetnek. Hamvas kérte még, hogy azon gyerekekről külön is gondoskodjanak, akik nem jelentkeztek hitoktatásra. Kapjanak majd ök is valahogyan hittankönyveket. Majd a föpásztor az értekezlet végén imában kérte Isten kegyelmét és áldását a hitoktatókra. ${ }^{58}$

1949 utolsó hónapjaiban már tankönyvhiány lépett fel az egyházmegyében. A kormányzat tudatos, a hitéletet és hitoktatást akadályozó magatartását mutatja dr. Halász Pál apátkanonok levele, amelyet püspökéhez intézett 1949. november 2-án, és amelyben leírja, hogy még a „házi használatra” készített hitoktatási anyagok nyomdai elkészíttetésére sincs módja a papságnak:

„A legutóbbi papi konferencián bemutatott ${ }^{59} » H i t$ és élet« c. - elsősorban a gyermekeiket oktató szülők használatára szerkesztett - füzet második és harmadik része is elkészült. Megbízásából dolgoztak arra az esetre, amikor a hitoktatás fokozott mértékben, sőt talán teljesen a szülők feladata lesz. Minthogy közvetlenül maguk a szerzők nem találnak a sokszorosításra lehetőséget, többfelé tájékozódtak, nem lehetne-e hittankönyvek közé sorolni, mint segédkönyvet, vagy mint hittani olvas- 
mányt, vagy talán más tituluson. Minthogy a hittankönyvek engedélyezése tárgyában Nagyméltóságod járt el illetékes helyen, méltóztassék megengedni, hogy a kérdést először elvileg felvessem. Amennyiben Nagyméltóságod megkísérelhetőnek látná az engedélyezés kérését, a szükséges három gépelt példányról tudnék haladéktalanul gondoskodni." 60

Az 1950/51-es tanében igen sok negatív képet festő hitoktatási jelentés született. Nehezítő körülményekről tudósít ebből a tanévből például Gimes Gyula ${ }^{61}$, a szentmihályi plébános: a helyi iskola 220 tanulója közül már csak 150 jelentkezett hittan-oktatásra, továbbá megjegyzi: „Pusztán az az oka, hogy nem jelentkeztek sokkal nagyobb számban, hogy munkaidő volt, és nem értesültek idejében mindannyian a jelentkezés lehetőségéről. ${ }^{62}$

A domaszéki jelentés szerint a diákoknak már csak 25 százaléka jelentkezett hittanra a területen, vagy ennél a számnál még kevesebben. ${ }^{63}$ A beszámolóban több, környékbeli iskola helyzetét is összefoglalja Nagy András lelkész. Általános probléma volt a beiratkozási idő rövidsége, valamint a szülők dezinformálása. A második beiratkozási időpontról az iskoláktól már nem kaptak értesítést a szülök. Majd levele végén megjegyzi, hogy sem ő, sem a segédlelkész nem kapott hitoktatói engedélyt. A szegedi, belvárosi iskolákban ekkorra szinte megszűnt a hitoktatás. Dániel Géza áldozópap jelentette novemberben, hogy a helyzetből következően szegedi hitoktatói állása megszünt, munkakör és fizetés nélkül él. ${ }^{64} \mathrm{~A}$ szülők Ferencszálláson és Klárafalván nem szerezhettek tudomást a beiratkozás határidejéről. ${ }^{65}$ Ökrös László főesperes, lelkész ezt írja:

„A második határidőt Ferencszállásra vonatkozólag egyáltalában nem közölték, csak oly módon, hogy a kiszombori iskola hirdetőtáblájára írták ki a határidő előtti estén. Ezt a hirdetőtáblát természetesen senki sem olvasta. A klárafalvai szülők egy része valahogy tudomást szerzett a határidőről, be is mentek Kiszomborra (a két iskola ugyanis a kiszombori igazgató alá tartozik) de ott csak 4 tanuló jelentkezését fogadták el.",66

Erről a tanévről írja Ugi Géza újszegedi plébános, hogy a hitoktatást az iskola részéről akadályozzák:

„,...] Több ízben fölkerestük az újszegedi általános iskola igazgatóját és érdeklődtünk a kapott miniszteri leirat értelmében a jelentkezés lehetőségéről. Utóbb írásban is kértük az igazgatót, hogy bennünket a rendelet megérkezésekor értesítsen. A templomban a hívek figyelmét felhívtuk az esetleges újabb jelentkezés lehetőségére. A rendelet megérkezésekor sem élőszóval, sem írásban értesítést nem kaptunk s így nem is állott módunkban a szülőket jelentkezésre küldeni. Értesítést sehonnan sem kaptunk a jelentkezésre." ${ }^{\prime 67}$

A hitoktatási nehézségekre jellemző esetet olvashatunk Szalma József püspöki tanácsostól, amely beszámolóban a szőregi hitoktatás nehézségeit vázolta: ${ }^{68}$

„[...] Azonban némi akadályok merültek fel. A kijelölt iskolában és teremben ugyanis, ahol az alsó osztályosokat tanítom, nincs semmiféle világítókészség és úgy a gyakorlatban csak félórákat taníthatok, miután félöt órakor már teljesen sötét a terem és így kellő fegyelmet nem tudok tartani. De van más nehézség is. A IV. osztálynak a kijelölt napokon egészen félöt óráig van előadása és így azokat egyelöre, míg ez a téli sötétség tart nem tudom bevonni a hitoktatásba.” 
A szegedi, felsővárosi plébános is jelentette, hogy a hittanoktatással kapcsolatos információkat az iskolai igazgatók hivatalos titokként kezelik. ${ }^{69}$ Almáskamaráson pedig Wéber Mihály plébános az iskolaigazgató rendíthetetlen ellenállásáról ír jelentésében. A szülők levelet írtak a plébániának, amelyet a pap mellékelt a püspökségnek küldött beszámolójában: „Alulírott szülők kijelentjük, hogy a mai napon mi és még többen az almáskamarási ált. állami iskola igazgatója előtt jelentkeztünk, hogy gyermekeinket hittanra járassuk, amit azonban az iskola igazgatója - hivatkozással arra, hogy felsőbb utasítást még nem kapott - nem fogadta el. (Szülők aláírása.)."70

A békepapi mozgalom egyházmegyei organizálása az államrendnek nehézkesen indult. A munkálatokban a megyei párt- és az állami szervek is részt vettek. Az első alakuló ülésen, 1950. május 10-én mindössze hét pap volt jelent, a gyülés kudarcba fulladt. De későbbre az államhatalmi intézkedések megtörték az ellenállást. Az ÁEH hivatalnokai kierőszakolták a püspöktől, hogy a vezető tisztségekre békepapokat nevezzen ki, az addigi tisztségviselőket pedig váltsa le. Így került nyugállományba Raskó Sándor püspöki helynök és Sopsich János püspöki irodaigazgató is. A következő békepapi alakuló ülésre, 1951. július 17-re már hetven pap ment el. Onnantól Hamvas püspöki körlevei is megfeleltek a politikai kívánalmaknak. A szentmise keretében fölolvasottak leginkább békemozgalmi témákat hangoztattak, ilyen és hasonló tartalmakkal: a szocializmus elismerése, a termelöszövetkezeti munka erkölcsi megalapozása, munkára buzdítás, begyüjtési kötelezettség teljesítése, társadalmi tulajdon védelme és a békekölcsönök jegyzése ( $P a ́ l, 2010$, 417-418. o.).

A levéltári dokumentumok között az 1952/53-as tanévből Jóboru Magda, a kultuszminiszter első helyettesének levelét találjuk. Március 21-i keltezéssel felhívja az iskolaigazgatók figyelmét, hogy a húsvét hétfő az iskolákban rendes munkanapnak számít, ezért folyó év április 6-án reggel 8 órakor kezdődik mindenhol a tanítás. ${ }^{71}$

Ebben a tanévben az újszegedi plébánia már arról jelentett, hogy a körzetben egyáltalán nem volt hitoktatás. A püspök válaszlevelében további jelentést várt Ugi Géza
A békepapi mozgalom egyházmegyei organizálása az államrendnek nehézkesen indult. A munkálatokban a megyei párt-és az állami szervek is részt vettek. Az elsó alakuló iülésen, 1950. május 10-én mindöszsze hét pap volt jelent, a gyúlés kudarcba fulladt. De késóbbre az államhatalmi intézkedések.

megtörték az ellenállást. Az ÁEH hivatalnokai kierószakolták a püspöktól, hogy a vezetố tisztségekre békepapokat nevezzen ki, az addigi tisztségviselóket pedig váltsa le. Így került nyugállományba Raskó Sándor püspöki helynök és Sopsich János püspöki irodaigazgató is. A következó békepapi alakuló ülésre, 1951. július 17-re már hetven pap ment el. Onnantól Hamvas püspöki körlevei is megfeleltek a politikai kívánalmaknak. A szentmise keretében fölolvasottak leginkább békemozgalmi témákat hangoztattak, ilyen és hasonló tartalmakkal: a szocializmus elismerése, a

termelöszövetkezeti munka erkölcsi megalapozása, munkára buzditás, begyújtési kötelezettség teljesitése, társadalmi tulajdon védelme és a békekölcsönök jegyzése (Pál, 2010, 417-418. о.). 
plébánostól. A levél tartalma a szegedi városi tanács negatív hozzáállását sugallja. A körzetbe ki sem neveztek hitoktatót. A gyomai plébános, Bodnár János tollából egy több évet átfogó, elszomorító jelentést olvashatunk a Püspöki Levéltárban:

„Tárgyban tisztelettel jelentem: Az 1952/53 iskolai évben a gyomai egyházközségnek nem volt hittanórája. - Egy sem jelentkezett. Az 1953/54 iskolai évben egyetlen gyermek jelentkezett, így ebben az iskolai évben sem kaptunk hittanórát. Az 1951/52 iskolai évben a tanyavilágban már nem volt hittanóránk, a belterületen még volt heti négy óra. A plébános megtartotta egész évben."72

1953-ban Kétegyházáról Marycz János plébános ezt írta:

„Az 1952/53 t. évben - nem a jelentkezők hiánya miatt - nem volt hitoktatás hanem azért, mert a hittan beíratásnál - az iskolai szervek - módot találtak arra - hogy a kb. 70-80 jelentkező létszámát - ha jól emlékszem - 17-re lecsökkentették. Ilyen kevés tanulóra az illetékesek pedig nem tartották érdemesnek hittanórát engedélyezni. ${ }^{73}$

Hunn Ernő kismarjai lelkipásztor is az iskola akadályozásáról jelentett:

„Heti 1 órában kaptam engedélyt a Kismarjai Általános Állami iskolához is a Megyei Tanács oktatási osztályától. Amikor azonban jelentkeztem az Iskola Igazgatójánál s kértem a hittan órám beosztását, nem engedte a hittanórák megkezdését azon indoklással, hogy időközben lemorzsolódott a jelentkezők száma. De még ebben az időben is volt 13 katolikus gyermek, kinek szülei nem léptek vissza a hitoktatás kérésétől. A reá következő héten 7-re lemorzsolták a jelentkezők számát."74

Az 1953/54-es tanév beszámolói között - rímelve más plébániák az évi beszámolóira - Szikora Károly plébános a hittanórák egyeztetési nehézségeiröl tudósít, amelynek hátterében a tankerület tudatos munkája állt. Ezt írta Szikora:

„Kiszomboron október 5-én megkezdődött a hitoktatás. Azonban Varga Ferenc segédlelkész egymagában képtelen mind a négy iskolában elvégezni a vallásoktatást, mivel egyidöre két hittanóra is esik". ${ }^{75}$

1956 nyarára bizonyítást nyert a Rákosi-rendszer materiális oktatási rendszerének mihasznasága. Ezt maga a kormány oktatási miniszterhelyettese volt kénytelen leleplezni. A Szabad Népben, az MDP napilapjában Sok a házi feladat, túlterheltek a gyerekek címmel jelent meg a beszámoló, amely a következő tanév előkészítő értekezletéről készült 1956 augusztusában:

„A tanévelőkészítő országos értekezlet szombati tanácskozásain Kiss Gyula oktatási miniszterhelyettes az új alsótagozati tanterv és tankönyvek bevezetése címen tartott előadást. [...] Ezután elmondotta, hogy az 1950-ben bevezetett tantervnek igen sok hibája volt. Hasztalan igyekeztek a pedagógusok, nem tudták elérni, hogy a negyedik osztály végére minden tanuló megfelelő olvasási, írási, helyesírási, fogalmazási, számolási készséggel rendelkezzék. A szülők minden jószándék ellenére sem tudtak segíteni az otthoni tanulásban, mert a tankönyvekböl alig lehetett figyelemmel kísérni az iskolai munkát. A tanterv általában kevés időt adott az ismeretek megszilárdítására, gyakorlására, a készségek megalapozására. Sok volt a házi feladat, s a gyerekeknek kevés idejük maradt a játékra, pihenésre. Egyes osz- 
tályokban már fel-feltünt egész iskolai munkánk nagy problémája, a gyermek túlterhelése. A pedagógusok igen kevés segítséget kaptak az anyag feldolgozásához. Az ilyen tanácsokkal: »...mindezekről a gyermekek értelmi fokozatának megfelelően kell beszélni...« nem sokat tudtak kezdeni, legfeljebb iskolánként különbözö színvonalon folyt az oktatás." 76

A rendszer tarthatatlanságának jelei tehát már az oktatáspolitikában is megmutatkoztak. A forradalom, ha nem is teljes, de enyhe könnyebbséget hozott az egyházi oktatók számára. A „leleplező" Kiss Gyula miniszterhelyettes utasítást adott a hitoktatással kapcsolatos kérdésekben 1957. január 1-én, amely levél megtalálható a püspöki levéltárban:

„A hitoktatással kapcsolatban az utóbbi hetekben felmerülő kérdések helyes és egységes rendezése érdekében az alábbiakban intézkedem: Az összes illetékes oktatási szervek - oktatási osztályvezetők, általános iskolai, gimnáziumi, és szakközépiskolai igazgatók - biztosítsák az adminisztratív megkötöttségektől mentes fakultatív hitoktatást. Tehát a tanulók a hittanórákon külön beiratkozás nélkül - kizárólag szüleik szabad elhatározása alapján - vehetnek részt. A múltban alkalmazott adminisztratív eljárások miatt várható, hogy a hitoktatásban résztvevők száma emelkedni fog, s mindezek alapján az újabb hitoktatói megbízások kiadása, valamint több óradíj biztosítása válik szükségessé. Az utóbbi kérdésekben a helyezet felismerése és az illetékesekkel folytatott tárgyalások után később intézkedem. »Tájékoztatásul addig is közlöm, hogy a hitoktatókat az illetékes egyházi szervek bízzák meg s az oktatásügyi hatóságok a megbízást tudomásul veszik.«"77

Kádár János kormánya a társadalom túlfeszített állapotán az egyházpolitika oldaláról is lazítani próbált az 1956-os események után. Az egyházmegyei levéltárban fellelhető iratok alapján komoly eredmények voltak tapasztalhatóak a hitoktatással kapcsolatos enyhítő intézkedés következtében. De már a rendeletet megelőzően, közvetlenül a forradalom napjai után is érzékelhető volt a szülők és a gyermekek lelkesedése.

Dániel Géza, Szeged - Petőfitelep plébánosa a következőt jelenti a Hivatalnak 1957. január 9-én a megelőző év utolsó hónapjairól:

„,...] Az általános iskolák hittanóráinak számát nem tudjuk véglegesen megállapítani, mert a hivatalosan közölt jelentkezők számadatainál jóval nagyobb számban vettek részt a tanulók a karácsony elött megtartott egy-egy hittanórán és így az iskolák által alkotott tanulócsoportok nem megfelelőek. [...] Az egyes osztályok összes róm. kat. vallású tanulói résztvettek a hittanórán.”78

1956. december 18-án hasonló eredményekről tudósított a rókusi plébános ${ }^{79}$ Szeged belvárosának hitoktatási helyzetéröl:

„Az összes iskolában a hittan csak rendes tanterven kívül tanítható. A tanulók nagy létszáma miatt azonban nem áll elégséges tanterem rendelkezésre, a tanterven kívüli hitoktatásra. [...] Minden iskolában megállapodtam az igazgatókkal, hogy hétfőn f. hó 17-én megkezdjük az oktatást, egyelőre heti egy órában, hogy a szünet elött, mely hétfön, 24-én kezdődik, minden osztályba eljuthassunk." 80

A különleges helyzetre reagálva, a Csanádi püspökség egy hitoktatási tervet dolgozott ki, amely a folyó tanév második felétől (1957. február) volt érvényes. Az irat lényegesebb részeit érdemes áttekintenünk: 
„A rendkívüli körülmények között megindult nagyobb arányú hitoktatás tanítástervének megírása felelősségteljes munka. Növendékeink hosszú idő múltán, vagy éppen először találkoznak az Egyház megbízott képviselőivel. S ettől az első találkozástól, a vele kapcsolatos első benyomásoktól, élményektől nagyon sok függ. (Erre gondolnak azok a világi nevelök is, akik egyre sürgetően kérik, hogy most nagyon jó hitoktatókat kapjanak az iskolák, s azok ott nagyon jó hitoktatást végezzenek.) [...] Gyakorlott, tapasztalatokban gazdag nevelők ajánlják, hogy ebben a félévben a hitoktatás ne legyen a szó szokott értelmében vett tanítás. Közvetlen életközelségben beszéljük át a legfontosabb igazságokat úgy, hogy azok logikájukkal és szépségükkel, egészségükkel hassanak, és élményt jelentsenek. [...] Népünkben, következésképpen gyermekeinkben is, nagyon meggyengült a hit. Életformáló ereje úgyszólván nincs. Vissza kell adnunk ezt a nagy kincset az embereknek. Föl kell tehát használni minden alkalmat arra, hogy megértessük szükségességét, megtanítsuk megszerzésének és növelésének módját. [...] A hit akkor eleven, ha valóban alakítja, formálja az életet. Hatása tehát elsősorban a cselekedetekben mutatkozik meg. Éppen ezért tehát folytatólagos gondunk (elsősorban a parancsokkal kapcsolatban) a lelkiismeret és majd a világnézet kialakítása. Fordítsunk tehát gondot a helyes értékelés elsajátítására! Minden más most részletnek számít, s ezért máskorra marad. [...] Tanmenetünk összeállításánál rugalmasságra kell törekednünk. Még nem tudjuk, mennyi idő áll rendelkezésünkre. A témákat össze lehet vonni. Elhagyni azonban kár lenne belőle. Régi, gyakorlott hitoktató kérése az is, hogy minden osztályban ezeket a témákat beszéljék meg a hitoktatók. Különösebb nehézséget nem jelent egyiket sem elöadni gyermekhangon vagy felnőttesen. Tudjuk, a gyermeknek érzéke van a természetfelettihez is! [...] Mindennél fontosabb azonban a Szentlélek szorgos segítségül hívása! A Nagy Segítővel biztosabb a siker, vagy legalább megoszlik a felelősség." 81

Ugyanebben az időszakban $A$ hitoktatás kérdése címen egy kiáltványban fogalmazta meg álláspontját az egyházmegye, amelynek jelen dolgozat szempontjából érdekes részeit ugyancsak érdemes végignéznünk:

„A pedagógusok szakszervezete azt a gondolatot vetette fel, hogy a hitoktatást az iskolából távolítsák el és utalják a templomokba. Nem hisszük, hogy ez a pedagógusok többségének véleménye. Egyébként ehhez a szülőknek is van hozzászólási joguk, ők pedig az iskolai hitoktatást kívánják. A hitoktatásnak az iskolából való eltávolítása még azt a kevés jogot is elvenné tőlünk, ami a hitoktatás terén számunkra még megmaradt. A hitoktatást a templomba szorítani ugyanis annyi, mint azt lehetetlenné tenni. [...] A mi kívánságunk tehát csak az lehet, hogy a hitoktatást az iskolákban állítsák vissza. Ez a szülők követelése. (Amely szülő nem akarja a gyermekét hittanra járatni, beíratáskor jelentse be.) Ausztriában, ahol a parlamenti képviselőknek csaknem fele szocialista, mégis a szülőknek jóval több, mint 90\%-a a hitoktatás mellett foglalt állást. Régi megállapítás, hogy vallás nélkül nem lehet nevelni. A keresztény vallásban oly nevelö értékek vannak, amelyek semmilyen ideológiával nem pótolhatók. Ezt elfogulatlan pedagógusok mindig vallották, sőt tapasztalattal is alátámasztották, ezért hisszük és reméljük, hogy a szülök jogos kívánsága a vallásos és hathatós erkölcsi nevelés érdekében a kormánynál is megértésre talál." 82

Az 1956-os események után a Kádár-kormány az egyik társadalmi szelepet az adminisztráció nélküli fakultatív hitoktatásban látta. A szülők éltek is a lehetőséggel, az országban tömegek látogatták a papok tanóráit. Ám a kormányrendeletet felülírta a politika, ugyan- 
is nem sokkal később, 1957. január 29-én dr. Kónya Albert oktatásügyi kormánybiztos Hamvas Endrének megküldött levele így szólt:

„A kormány nyilatkozata leszögezte, hogy »az iskolákba, teljes mértékben biztosítja a fakultatív hitoktatást, vagyis a vallásoktatásban való részvétel, vagy részt nem vétel szabadságát.« Iskoláinkban azonban az elmúlt hetekben a politikai reakció tevékenysége következtében olyan helyzet alakult ki, melyben nincs biztosítva a vallásoktatásban való részt nem vétel szabadsága. Ez a helyzet súlyosan zavarja az iskolai élet rendjét, fegyelmét, gátolja a megrövidült tanév eredményes befejezését és károsan befolyásolja az ifjúság nevelését. Ezért - az 5/1957/ O. K. 1./1957. I. 1./ és 852/853-2/1957. V. föoszt. számú utasításokat visszavonva - elrendelem, hogy az 1956/57-es tanévben, hitoktatásban csak azok vehetnek részt, akiket szüleik e tanév megkezdése előtt hitoktatásra szabályszerüen beírattak. A hitoktatásra való új jelentkezésekre a következő tanévi beiratkozáskor lesz mód." 83

A csanádi főpásztornak küldött levél alapján ez időtől tehát mind az egyházmegyei, mind az országos hitoktatás visszakerült régi medrébe.

\section{Összegzés}

A dolgozatban bemutatott 1945 és 1956 közötti egyházmegyei hitoktatás az országos történések tökéletes leképeződése. A sztálini mintájú hazai erőpolitika évről évre tudatosan gyengítette az egyház müködését. A „nép ópiumának” tartott vallást minden körülmények között vétkes jelenségnek, a papságot pedig a demokrácia fejlődését gátló „reakciónak” állította be a kommunista hatalom. A szovjetizálódás folyamatában a felnőtt társadalom átnevelése mellett gondosan ügyeltek az új generációra is. A Csanádi Egyházmegye hitoktatási beszámolóit vizsgálva az 1950-es évek elejére már nagyon kevesen vagy egyáltalán nem ültek a padokban a hittanórákon. De hogy a felszín alatt mi volt, a családok vallásossága milyen képet mutatott, arról az 1956-os forradalom utáni néhány hétben lehetett meggyőződni.

Látnunk kell ugyanis, hogy a sajtóhadjáratok, a hitbuzgalmi egyesületek betiltása, a népbírósági perek, Mindszenty letartóztatása és bebörtönzése, majd más egyháziak meghurcolása, és a békepapi mozgalom, valamint a hazugságok és a sorozatos megfélemlítések a tanintézményekben gondoskodtak arról, hogy a családok idegenkedjenek az egyháztól és a hitélettől. A kommunisták bíztak abban, hogy rövid időn belül egy másik, saját szájuk íze szerint müködő, materiális gondolkodású társadalmat tudnak felépíteni, amelynek alapjait az iskolákban kezdték el lerakni, az alapfokú intézményektől egészen az egyetemekig. De terveik eredménytelenségére példa, hogy az 1956-os forradalom után tömegek látogatták a hittanórákat.

\section{Forrásjegyzék}

Magyar Nemzeti Levéltár Csongrád Megyei Levéltára. Csanád Vármegye és Szeged tanfelügyelőségi iratai. VI. 504. fond. - 1335/1947. - A vármegyei szülöi értekezletekről szóló tanügyi beszámolók.

Magyar Nemzeti Levéltár Csongrád Megyei Levéltára. Csongrád Megyei Tanács V.B. Oktatási és Népmüvelési Osztály iratai. - XXIII. fond. - 52/B. - 2/1953.
- Jóboru Magda kultuszminiszter-helyettes levele a tankerület igazgatóihoz.

Magyar Nemzeti Levéltár Csongrád Megyei Levéltára. Szeged tanfelügyelöségi iratai. XXIV. 503. fond. - 3259/1948. - Iskolák államositásával kapcsolatos iratok. 
Magyar Nemzeti Levéltár Csongrád Megyei Levéltára. Szegedi Népbíróság iratai. XXV. 6. fond 194/1947; 312/1947. - Szélpál István és Kovács Józsefné népbirósági aktái.

A Magyar Vallás- és Közoktatásügyi Minisztérium 23.242/1948. I. f. o. ügyszámú levele.
Szeged - Csanádi Püspöki és Székeskáptalani Levéltár dokumentumai, I. 1. a; I. 1. f; I. 1. h. fondok Egyházi igazgatási iratok.

\section{Irodalomjegyzék}

Bakos Ferenc (1994): Idegen szavak és kifejezések szótára. Akadémiai Kiadó, Budapest.

Balogh Margit és Gergely Jenő (1993): Egyházak az újkori Magyarországon. MTA Történettudományi Intézete, Budapest

Balogh Margit és Szabó Csaba (2001): A Grősz-per. Kossuth Kiadó, Budapest.

Bálint László (2002): Diákmegmozdulások Szegeden 1947-ben. Szegedi Mühely, 3-4. sz.

Bögre Zsuzsa (1998): Békepapság az üldözött egyházban. In: Szerkesztők neve? Studia Religiosa Tanulmányok András Imre 70. születésnapjára. Bába és Társa Kiadó, Szeged.

Dr. Csepregi Imre (2012): Napló 2. 1947-1948. Makó.

Gergely Jenő (1977): A politikai katolicizmus Magyarországon 1890-1950. Kossuth Könyvkiadó, Budapest.

Gergely Jenő (1985): A katolikus egyház Magyarországon 1944-1971. Kossuth Könyvkiadó, Budapest.

Gergely Jenő (1999): A katolikus egyház története Magyarországon 1919-1945. Pannonica Kiadó, Budapest.

Gyarmati György, Botos János, Zinner Tibor és Korom Mihály (1988): Magyar hétköznapok Rákosi Mátyás két emigrációja között, 1945-1956. Minerva Kiadó, Budapest.

Lénárd Ödön, Tímár Ágnes és Soós Viktor Attila (2008): Istennel, vagy Isten nélkül. A katolikus iskolák államositása Magyarországon a II. világháború után. Kairosz Kiadó. Budapest.

Magyar Katolikus Lexikon. (1998, 2001, 2002, 2004, 2005, 2008, 2010) Szent István Társulat, Budapest.

Medgyesi Konstantin (2000): Mindszenty biboros és a Marosmenti Mária-napok. Móra Ferenc Múzeum, Szeged.

Máthé Zsuzsa (2011): Kiss Szaléz - Keresztény közéleti személyiségek a XX. században. Kairosz Kiadó, Budapest.
Mészáros István (1996): A magyar nevelés- és iskolatörténet kronológiája 996-1996. Nemzeti Tankönyvkiadó, Budapest.

Mészáros István (1989): Mindszenty és Ortutay Iskolatörténeti vázlat, 1945-1948. A szerző magánkiadása, Budapest.

Mészáros István (2004): Ortutay Gyula kultuszminisztersége és a Magyar Katolikus Egyház. Szent István Társulat, Budapest.

Mészáros István (2005): Mindszenty a Sándor Palotában - Hat tanulmány. Eötvös József Könyvkiadó, Budapest.

Mindszenty József (1989): Emlékirataim. Apostoli Szentszék Könyvkiadója, Budapest.

Oktatásügyi Közlöny (1957. január 1.), 5. 1. sz.

Orbán Sándor (1962): Egyház és Állam 1945-1950. Kossuth Kiadó, Budapest.

Pál József (2010): A szegedi egyházak története 1944-1990. In: Móra Ferenc Múzeum Évkönyve. Történeti Tanulmányok - Studia Historica 13. Szeged.

Petrás Éva (2015): A kereszténydemokrácia eszmetörténeti elözményei Magyarországon. Szent Vince Kollégium és Szakkollégium, Piliscsaba.

Péter László (2007): Az én besúgóim. F-dossziém. Belvedere Kiadó, Szeged.

Révai József (1948): Egyházellenes-e a demokrácia? In: uő: Élni tudtunk a szabadsággal. Összegyüjtött beszédek, irások. Szikra Kiadó, Budapest.

Sulyok Dezső (2004): Két éjszaka nappal nélkül. Éghajlat Könyvkiadó, Budapest.

Szabó Csaba (2001): A Grősz-per előkészítése. Osiris - Budapest Főváros Levéltára, Budapest.

Zombori István (2005): A Szeged-Csanádi Püspökség - Egyházmegyei Múzeum és Kincstár. Szeged-Csanádi Püspökség. Szeged. 


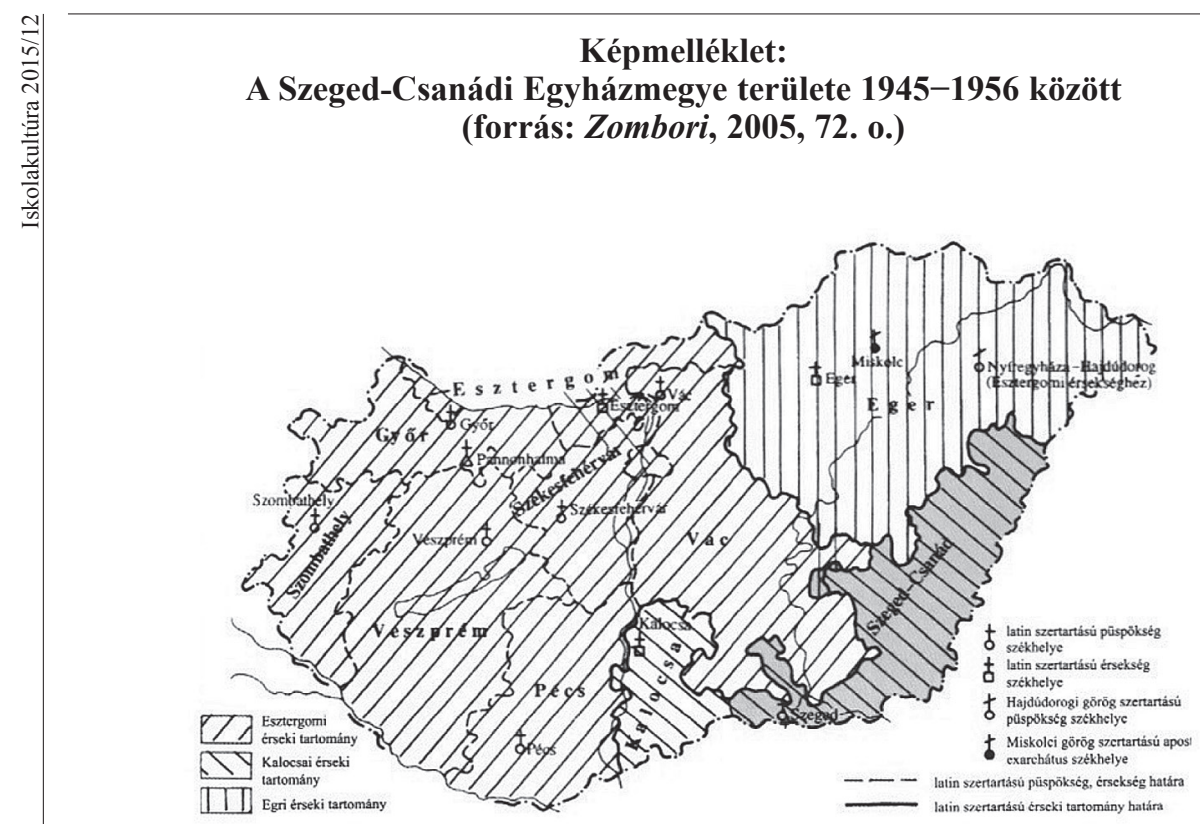

Szeged - Csanádi Egyházmegye területi elhelyezkedése 1938 és 1993 között. (In.: Zombori István: A Szeged-Csanádi Püspökség - Egyházmegyei Múzeum és Kincstár (Szeged - Csanádi Püspökség. Szeged, 2005. 72. )

\section{Jegyzetek}

${ }^{1}$ Ld. Magyarország a XX. században/Magyar népesség, 2015. 07. 30-i megtekintés, http://mek.oszk. hu/02100/02185/html/171.html

${ }^{2}$ Prohászka Ottokár (Nyitra, 1858 - Budapest, 1927): Esztergomban tanult teológiát, majd 1881-ben szentelték pappá Rómában, ahol doktorátust is szerzett. 1905-től volt Székesfehérvár püspöke. Az első világháború után nemzetgyülési képviselő (2015. 08. 24-i megtekintés, http://lexikon.katolikus.hu/P/Proh\%C3$\%$ A1szka.html).

${ }^{3}$ Katholikus Néppárt (1894-1918): A „Rerum novarum” szellemében, az egyház szociális tanításait elsőként képviselő párt Magyarországon. Prohászka ösztönzésére Gróf Zichy Nándor és Gróf Esterházy Miklós voltak az alapítók. Szavazótábora a városi polgárság, a jómódú parasztság képviselői voltak. 1918-ban összeolvadva a keresztényszocialistákkal megalakították a Keresztényszociális Néppártot (2015. 08. 24-i megtekintés, http://lexikon.katolikus.hu/K/Katholikus\%20N\%C3\%A9pp\%C3\%A1rt.html).

${ }^{4}$ Bangha Béla (Nyitra, 1880 - Budapest, 1940): Nemzetközileg is elismert hithirdető, szerkesztő, író. Az 1938-as, budapesti Eucharisztikus Világkongresszus fő szervezője (2015. 08. 24-i megtekintés, http://lexikon.katolikus.hu/B/Bangha.html).

${ }^{5}$ Giesswein Sándor (Komárom, 1856 - Budapest, 1923): Nyelvész, vallástörténész, kanonok. 1878-ban, a győri egyházmegyében szenteltették pappá, 1880 tól a teológia doktora. Híve volt a demokratikus szabadságjogoknak, a munkásság szervezkedési szabadságának (2015. 08. 24-i megtekintés, http://lexikon. katolikus.hu/G/Giesswein.html).

${ }^{6}$ Sík Sándor (Budapest, 1889 - Budapest, 1963): Tartományfőnök, egyetemi tanár, költő. 1903-ban lépett a rendbe, majd 1911-ben szentelték pappá. Magyar-latin tanári oklevelet szerzett és filozófiából doktorált. 1929-1944 között a szegedi egyetem irodalomtörténet tanára volt. 1945-től az Országos Köznevelési Tanács ügyvezető elnöke, 1947-től a piaristák tartományfönöke. Mint rendfőnök 1950-ben részt vett az állam és egyház közötti tárgyalásokon (2015. 08. 24-i megtekintés, http://lexikon.katolikus. hu/S/S\%C3\%ADk.html).

${ }^{7}$ Gróf Teleki Géza (Budapest, 1911 - USA, 1983): Teleki Pál miniszterelnök fia. A bécsi egyetemen végzett 1936-ban, földrajzból doktorált. 1944-től vallás- és közoktatásügyi miniszter az ideiglenes kormányban. 1945-től a Polgári Demokrata Párt elnöke, majd a politikai támadások miatt erről a tisztségéről lemondott. 1947-ben az USA-ba menekült (2015. 08. 24-i megtekintés, http://lexikon.katolikus.hu/T/Teleki.html).

${ }^{8}$ Rákosi Mátyás (Ada, 1892 - Gorkij, Szovjetunió, 1971): 12 évesen Rosenfeldről Rákosira magyarosította a nevét. A Keleti Kereskedelmi Főiskola 
elvégzése után európai nagyvárosokban volt ösztöndíjas. Az első világháború után, szerbiai hadifogságából hazaszökve aktív munkát végzett a Kommunisták Magyarországi Pártjának megszervezésében. A Tanácsköztársaság idején népbiztos, majd politikai okokból távoznia kellett az országból. 1924-ben újra itthon kezdte meg illegális szervező tevékenységét, amelynek következtében kilencévnyi börtönt kapott, majd 1934-ben életfogytiglanra ítélik. Egy államközi megegyezés értelmében Vas Zoltánnal együtt a Szovjetunióba távozhatott (csereegyezmény volt: ereklyéket, 1848-as honvéd lobogókat kapott értük cserébe az ország). Kinn az emigráns magyar pártszervezet vezetője volt. 1944-ben hazatért és helyet kapott az Ideiglenes Nemzetgyülésben, majd megkezdte a magyar kommunista diktatúra kiépítését. Szovjet támogatással, miniszteri funkcióban három év alatt felszámolta a többpártrendszert. „Sztálin legjobb magyar tanítványa": 1949-től a grúz származású diktátor példáját követve a gazdaság legfő́bb pilléreinek államosítása után sztálini mintára erőszakos szövetkezetesítésbe és az ipar átgondolatlan fejlesztésébe kezdett. 1953-tól a kiépített diktatúrája hanyatlani kezdett. Köszönhető volt ez politikája eredménytelenségének és Sztálin halálának. A szovjet központi vezetés bizalmát elveszítve kellett a hatalmat átadnia Nagy Imrének. Kevéssel utána, 1955-ben még kormányzó pozícióba került, de 1956-ra minden tisztségéről lemondatták. A forradalom után a Kádár-kormány a Kremllel egyetértésben a Szovjetunióba menesztette. A távoli Krasznodarból Kirgizisztánba, onnan pedig Gorkijba internálták, ahol 1971-ben hunyt el (2015. 08. 31-i megtekintés, http://www. rubicon.hu/magyar/oldalak/1971_februar_5_rakosi_matyas_halala/).

${ }^{9}$ Mindszenthy (Pehm) József (Csehimindszent, 1892 - Bécs, 1975): 1915-ben szentelték pappá. 1919-töl Zalaegerszegen látott el plébánosi szolgálatot. 1944töl veszprémi püspök, majd a zsidók elhurcolása elleni tiltakozása miatt a nyilas hatóságok börtönét élvezte. Sopronkőhidai „büntetése” után 1945-ben XII. Pius öt nevezte ki esztergomi érseknek, majd Magyarország hercegprímásának. A kommunisták által rendszerellenesnek tartott regnálása miatt 1948-ban koholt vádak alapján letartóztatták, majd életfogytiglani fegyházra ítélték. 1955-től házi őrizetben volt (Püspökszentlászló, Felsőpetény), majd 1956-ban szabadult. Az októberi forradalom napjaiban némi esély látszott a bíboros visszatérésére, ám 1956 novemberétől az USA budapesti nagykövetségének védelmében élt egészen 1974-ig. Ezután a bécsi Pázmáneumban találta meg nyugalmát (Magyar Katolikus Lexikon, 2004, 185-186. o.).

${ }^{10}$ 1946. évi VII. törvény a demokratikus államrend és köztársaság büntetöjogi védelméröl (2015. 07. 31-i megtekintés, http://www.1000ev.hu/index. php? $\mathrm{a}=3$ \&param $=8225$ ). A törvényt Sulyok Dezső minősítette így egy parlamenti felszólalásában, mert „gumiparagrafus" volt: az alapján bárkit, bármiért el lehetett ítélni (ld. Sulyok, 2004).
${ }^{11}$ Ortutay Gyula (Szeged, 1910 - Budapest, 1978): Katolikus értelmiségi család sarjaként 1934-ben végezte be egyetemi tanulmányait a szegedi Királyi Ferenc József Tudományegyetem magyar-latin-görög tanári szakán, ahol Sík Sándor tanítványa volt. Még ebben az évben magyar néplélektanból szerzett doktori fokozatot. Megalapítója volt a Szegedi Fiatalok Mủvészeti Kollégiumának, szoros barátság füzte Radnóti Miklóshoz. 1935 és 1944 között a Magyar Rádió kulturális osztályán dolgozik, annak helyettes vezetője. 1937-ben kapcsolódik az illegális kommunista munkásmozgalomhoz, 1942 nyarán a Magyar Történelmi Emlékbizottság egyik szervezője. 1944 ben elkészítette a Független Kisgazdapárt múvelődési-oktatási programját, majd a megszállás idején az ellenállási mozgalom tagja. 1945 és 1947 között a Magyar Rádió elnöke. 1945-től részt vesz a kisgazdapárt újjáépítésében, annak kulturális tagozatának elnöke. Mindezek mellett a kezdetektől tagja - anonim módon - a kommunista pártnak (kriptokommunista). 1947 és 1951 között vallás- és közoktatásügyi miniszter, 1953-ig országgyűlési képviselő. Néhány éves mellőzöttség után a Kádár-kormány híve 1957. től. A Hazafias Népfront főtitkára 1957-től egészen 1964-ig, közben 1957-1963 között az ELTE rektora. 1958-tól akadémikus, 1967-től haláláig az MTA Néprajzi Kutatócsoportjának igazgatója volt (2015. 08 27-i megtekintés, http://www.rev.hu/sulinet45/szerviz/kislex/biograf/ortutay_g.htm).

${ }^{12}$ Gróf Károlyi Mihály (Budapest, 1875 - Vence, Franciaország, 1955): A nagybirtokos Károlyi-család leszármazottja. 1901-től országgyülési képviselő, a liberális és szabadelvű politikai platformok támogatója, az uralkodói osztályok határozott ellenfele volt. Az I. világháború idején a béke mellett foglalt állást. Az 1918-as őszirózsás forradalom vezetö egyénisége, a Nemzeti Tanács vezetője. Miniszterelnök (1918. október 31. - 1919. január 11.), majd köztársasági elnök (1919. január 11. - 1919. március 21.). Lemondása után nyugatra emigrált és Franciaországban telepedett le. Külföldi előadókörútjain a Horthy-rendszert kritikával illette, népellenes és retrográdnak tartott politikája miatt. 1920-tól rendszeresen együttmüködött a magyarországi kommunistákkal, tagja volt antifasiszta szervezeteknek. 1946-ban hazatért, majd 1949-ig párizsi nagykövet. Élete utolsó éveit a politikától visszavonulva töltötte Franciaországban (2015. 08. 27-i megtekintés, http://mek.oszk. hu/00300/00355/html/ABC07165/07472.htm).

${ }^{13}$ Révai József (Budapest, 1898 - Balatonaliga, 1959): A kereskedelmi középiskola után Bécsben és Berlinben folytatott egyetemi tanulmányokat, tagja volt a Galilei Körnek. Az egyetem után banktisztviselöként dolgozott, közben verseket és irodalmi tanulmányokat írt. 1918-ban került kapcsolatba a magyarországi kommunistákkal. 1930-ban politikai tevékenysége miatt letartóztatták, három év börtön után a Szovjetunióba emigrált. Az ugyancsak moszkovita Gerő Ernővel együtt dolgozták ki a kommunista párt akcióprogramját a Szovjetunióban. 1944 novemberétől Szegeden együtt szerkesztette Erdei Ferenccel 
és Balogh Istvánnal a Magyar Nemzeti Függetlenségi Front lapját, a Délmagyarországot. 1945 és 1950 között a Szabad Nép föszerkesztője. Közben 1945-töl a kommunista párt propagandaosztályának vezetője. 1949. március 15-én a reakció ellen vívott publicisztikai „harca” miatt Rákosi Kossuth-díjjal tüntette ki. Lapszerkesztői munkássága után 1953-ig népmüvelési miniszter. Később irányítása alá került a párt kulturális osztálya, valamint felügyeletéhez tartozott a Társadalmi Szemle címü folyóirat. Az '56-os forradalom idején Moszkvába menekült, majd 1957-ben hazatért mint a Kádár-kormány tanácsadója. Élete utolsó részében József Attila-kutatással foglalkozott (2015. 08. 27-i megtekintés, http://www.rev.hu/sulinet45/szerviz/kislex/biograf/revai.htm).

${ }^{14}$ Zakar András (Margitta, 1912 - Székesfehérvár, 1986): Mérnök, áldozópap. 1945-től Mindszenty titkára. A Mindszenty-perben III. rendű vádlottként a demokratikus államrend megdöntésére irányuló szervezkedésben való részvételért és folytatólagosan, társtettesként megvalósított hütlenségért 6 évi fegyházra, 10 évi hivatalvesztésre és teljes vagyonelkobzásra ítélték, 1953-ban szabadult. 1970-ben rehabilitálták, majd haláláig kisegítő lelkészként dolgozott Budapesten (2015. 08. 24-i megtekintés, http://lexikon.katolikus.hu/Z/Zakar.html).

${ }^{15}$ Grősz József (1887. Féltorony - 1961. Kalocsa) 1911-ben szentelték pappá a bécsi Pázmáneumban. 1943-tól kalocsai érsek. Serédi halála után Mindszenty kinevezéséig a püspöki konferencia elnöke. 1948 végétől, Mindszenty bebörtönzése idején ugyanezt a teendőt látta el. 1950-ben az egyház nevében aláírta az állammal kötött egyezményt. 1951-ben letartóztatták, miniszteri engedéllyel 1955-ben börtönbüntetését megszakíthatta, majd 1956-ban kegyelmet kapott. Haláláig a püspöki kar elnöke volt (2015. 08. 24-i megtekintés, http://lexikon.katolikus.hu/G/ Gr\%C5\%91sz.html).

${ }^{16}$ Czapik Gyula (Szeged, 1887 - Budapest, 1956): 1910-ben pappá szentelik, 1929-től nagyváradi kanonok, 1939-től veszprémi megyéspüspök, 1943-tól egri érsek, a Felsőház tagja. A világháború után az egyház müködésének folyamatossága érdekében együttmüködik a kommunista hatalommal, aktív résztvevője a hazai és a nemzetközi békemozgalomnak. Tagja az Országos Béketanácsnak és a Hazafias Népfront Országos Tanácsának is (2015. 08. 27-i megtekintés, http://www.hdke.hu/tudastar/enciklopedia/czapik-gyula).

${ }^{17}$ Részletesen ld. a képmellékletben, a dolgozat végén (a térkép forrása: Zombori, 2005, 72. o.).

${ }^{18}$ Dr. Hamvas Endre (Piszke, 1890 - Kalocsa, 1970): 1913-ben doktorált teológiából, és szentelték pappá a bécsi Pázmáneumban.1940-től budapesti érseki helynök. 1944-től a Csanádi Egyházmegye Püspöke. 1964-től kalocsai érsek, majd 1968-ban betegsége miatt visszavonult hivatalától (Magyar Katolikus Lexikon, 1998, 567-568. o.).
${ }^{19}$ Dr. Halász Pál (Szeged, 1890 - Szeged, 1958): Apát-kanonok. 1913-ban szentelték pappá Esztergomban. Budapesten volt hittanár, majd 1931-ben átlépett a Csanádi Egyházmegyébe. 1934-től a szeged-móravárosi egyházközség plébánosa, 1946-ban címzetes apátnak nevezik ki (Magyar Katolikus Lexikon, 1998, 524. о.).

${ }^{20}$ Magyarországon 1920 és 1948 között, a Jézus Szentséges Szívét tisztelő és Jézusért apostolkodni akaró 6-14 éves fiúk és leányok szervezete volt. Célja a valláserkölcsi és hazafias nevelés elmélyítése volt (Magyar Katolikus Lexikon, 2008, 321. o.).

${ }^{21}$ Az intézmény mai neve: Szegedi Radnóti Miklós Kísérleti Gimnázium.

${ }^{22}$ SZCSPL. I. 1. a. - 1707/1944; 1945

${ }^{23}$ Katekézis: kérdés-felelet formájában történő hitoktatás (Bakos, 1994, 389. o.).

${ }^{24}$ SZCSPL. I. 1. a. - 1500/1945;1946

${ }^{25}$ Karácsonyi Guidó (Nagyrőce, 1885 - Orosháza, 1962): 1910-ben, Temesvárott szentelték pappá. Szegeden, Szöregen látott el plébánosi szolgálatot. 1950-től izgatás vádjával a szegedi Csillag börtönben töltötte büntetését 1952-ig. Haláláig Orosházán, Békéssámsonban, Maroslelén, Eleken, Bucsán és Mátraszentimrén volt lelkész (2015. 08. 24-i megtekintés, http://lexikon.katolikus.hu/K/Kar\%C3\%A1csonyi.html).

${ }^{26}$ SZCSPL. I. 1. a. - 1707/1944; 1945, valamint SZCSPL. I. 1. a. - 1500/1945; 1946 alapján.

${ }^{27}$ A hittanárok diákokhoz intézett buzdító szentbeszéde (Bakos, 1986, 239. o.).

${ }^{28}$ SZCSPL. I. 1. a - 1700/1947

${ }^{29}$ Más nagy városokban is jellemzőek voltak a tömegdemonstrációk. Zalaegerszegen például 12 000-en vonultak fel az utcákon (Lénárd, Tímár és Soós, 2008, 33-35. о.).

${ }^{30} \mathrm{Az}$ intézmény mai neve: Szegedi Vedres István Szolgáltatási Szakképző Iskola.

${ }^{31}$ Komócsin Mihály (Szeged, 1925-): 1940-től az illegális kommunista párt tagja volt. 1944-től az MKP nagy-szegedi területi szervezője, szakszervezeti felelőse. 1956 novemberétől az MSZMP szegedi pártszervezője. 1971-ig az MSZMP megyei bizottságának gazdaságpolitikai titkára. Ezután a megyei tanács elnöke, és 1985-ig a párt megyei első titkára és országgyülési képviselő (2015. 08. 24-i megtekintés, http://www.tortenelmitar.hu/index.php?option=com content \&view $=$ article $\&$ id $=4750 \&$ catid $=74 \% 3 \mathrm{Ak} \& \mathrm{I}-$ temid=67\&lang $=$ de).

${ }^{32}$ MNL-CSML, a Szegedi Népbíróság iratai. XXV. 6. fond, Nb. 194/1947 és Nb. 312/1947., Szélpál József és Kovács Józsefné népbírósági aktái.

${ }^{33}$ Délmagyarország, 1947. március 23., 2. o.; Délmagyarország, 1947. május 3., 3. o. 
Farkas László Róbert: Hitoktatás a Csanádi Római Katolikus Egyházmegyében 1945 és 1956 között

${ }^{34} \mathrm{Az}$ intézmény mai neve: Tömörkény István Gimnázium és Müvészeti Szakközépiskola.

${ }^{35}$ MNL-CSML, Csanád Vármegye és Szeged tanfelügyelőségi iratai. VI. 504. fond. - 1335/1947. - A vármegyei szülői értekezletekről szóló tanügyi beszámolók alapján.

${ }^{36}$ Köznevelés, 1947. április 1., 126. o. ${ }^{37}$ Uo.

${ }^{38}$ MNL - CSML: Szeged tanfelügyelőségi iratai. XXIV. 503. fond. - 3259/1948. - Iskolák államositásával kapcsolatos iratok alapján.

${ }^{39}$ Délmagyarország, 1948. június 20., 3. o.

${ }^{40}$ SZCSPL. - Püspöki körlevél: 1948. V. 2152. sz.

${ }^{41}$ Uo.

${ }^{42}$ Szöveghủ idézet, ahogyan a dolgozat további részében is minden egyezik az idézett forrással.

${ }^{43}$ Később idézett újságcikk címe (Csanádmegye, 4. 128. sz., 1948. június 6.). SZCSPL. 1300/1948.

${ }^{44}$ Litográfia: nyomdai kőnyomatot (Bakos, 1994, 462. o.).

${ }^{45}$ Csanádmegye, 4. 128. sz., 1948. június 6. 4. o.; SZCSPL. 1300/1948-as iratok.

${ }^{46}$ 2159. számú csanádi püspöki körlevél 1948-ból. SZCSPL. 2159/1948.

${ }^{47}$ Délmagyarország, 1948. május 28., 1. o

${ }^{48}$ A Magyar Vallás-, és Közoktatásügyi Minisztérium 23.242/1948. I. f. o. ügyszámú levele. - SZCSPL. -1948. V. 2151. számú Püspöki Körlevélben teljes terjedelmében és szöveghűen idézve.

${ }^{49}$ A szegedi papnevelő intézet.

${ }^{50}$ SZCSPL. I. 1. f. $-2414 / 1948$

${ }^{51}$ SZCSPL. I. 1. f. $-2414 / 1948$

${ }^{52}$ Havass Géza (Budapest, 1913 - Szeged, 2001): Plébános, hittanár. 1938-ban szentelték pappá Szegeden. Plébános és hittanár volt, majd 1943 és 1949 között püspöki titkár a Csanádi Egyházmegyében. Mindszenty letartóztatása után a politikai beszervezés elöl Budapestre menekült, ahol kisegítő káplánként müködött. 1957-ben visszakerül Szegedre, majd 1961-ben letartóztatták. Államrend ellen való szervezkedés vádjával 5 év és 6 hónap börtönbüntetésre ítélték. 1965-ben amnesztiával szabadult. Ezután a Szegedi Dóm kisegítő lelkésze volt, majd 1968-ból Újszegeden müködött plébánosként 1988-ig (Magyar Katolikus Lexikon, 1998, 656-657. o.).

${ }^{53}$ Merksz Elemér a szegedi papnevelő intézet, a Szent Gellért Szeminárium rektora volt 1953 és 1954 között
(2015. 08. 25-i megtekintés, Szent Gellért Szeminárium honlapja, www.szgsz.hu/eloljarok).

${ }^{54}$ SZCSPL. I. 1. f. $-2414 / 1948$

${ }^{55}$ SZCSPL. I. 1. f. $-102 / 1949$

${ }^{56}$ SZCSPL. I. 1. f. $-893 / 1949$.

${ }^{57}$ SZCSPL. I. 1. f. - 2252/1949

${ }^{58}$ Uo.

${ }^{59}$ A levél szerzője az előbbiekben említett, 1949 októberében megtartott egyházmegyei hitoktatói értekezletre utal.

${ }^{60}$ SZCSPL. I. 1. f. - 2323/1949

${ }^{61}$ Gimes Gyula (1914-1991): Plébános. A teológiát 1932/37-ben végezte Szegeden (2012. 12. 22-i megtekintés, Magyar Katolikus Lexikon, www.lexikon. katolikus.hu).

${ }^{62}$ SZCSPL. I. 1. h. $-74 / 1950$

${ }^{63}$ SZCSPL. I. 1. h. $-80 / 1950$

${ }^{64}$ SZCSPL. I. 1. h. $-2609 / 1950$

${ }^{65}$ SZCSPL. I. 1. h. $-64 / 1950$

${ }^{66}$ SZCSPL. I. 1. h. $-64 / 1950$

${ }^{67}$ SZCSPL. I. 1. h. $-134 / 1950$

${ }^{68}$ SZCSPL. I. 1. h. $-191 / 1950$

${ }^{69}$ Uo.

${ }^{70}$ SZCSPL. I. 1. h. $-1848 / 1950$

${ }^{71}$ MNL - CSML. Csongrád Megyei Tanács V.B. oktatási és népmüvelési osztály iratai. - XXIII. fond. $-52 / B .-2 / 1953$.

${ }^{72}$ SZCSPL. I. 1. h. $-1636 / 1953$

${ }^{73}$ SZCSPL. I. 1. h. $-1636 / 1950$

${ }^{74}$ SZCSPL. I. 1. h. $-1636 / 1950$

${ }^{75}$ SZCSPL. I. 1. h. $-2161 / 1950$

${ }^{76}$ Szabad Nép, 1956. augusztus 19., 2. o.

${ }^{77}$ Oktatásügyi Közlöny, 5. 1. sz., 1957. január 1.

${ }^{78}$ SZCSPL. I. 1. h. $-2348 / 1950$

${ }^{79}$ A saját kézzel aláírt dokumentumon a plébános neve olvashatatlan.

${ }^{80}$ SZCSPL. I. 1. h. $-2457 / 1956$

${ }^{81}$ SZCSPL. I. 1. h. $-150 / 1957$

${ }^{82}$ SZCSPL. I. 1. h. $-150 / 5$

${ }^{83}$ SZCSPL. I. 1. h. $-328 / 1957$. 